\title{
Electron-Capture and -Transfer Dissociation of Peptides Tagged with Tunable Fixed-Charge Groups: Structures and Dissociation Energetics
}

\author{
Thomas W. Chung, ${ }^{1}$ Christopher L. Moss, ${ }^{1}$ Magdalena Zimnicka, ${ }^{1}$ Richard S. Johnson, ${ }^{2}$ \\ Robert L. Moritz, ${ }^{2}$ František Tureček ${ }^{1}$ \\ ${ }^{1}$ Department of Chemistry, University of Washington, Bagley Hall, Box 351700, Seattle, WA 98195-1700, USA \\ ${ }^{2}$ Institute for Systems Biology, 1441 N 34th Street, Seattle, WA 98103-8904, USA
}

\begin{abstract}
Pyridiniummethylcarbonyl moieties that were previously designed on the basis of electronic structure analysis are now utilized as fixed-charge tags with tunable electronic properties to be used for $\mathrm{N}$-terminal peptide derivatization and sequencing by electron-transfer dissociation. Dipeptides $\mathrm{AK}$ and KA were derivatized at the peptide $\mathrm{N}$-terminus with 4-dimethylaminopyridinium-N-acetyl (DMAP-ac) and pyridinium-N-acetyl (pyrid-ac) tags of increasing intrinsic recombination energies. Upon the capture of a free electron or electron transfer from fluoranthene anions, (DMAP-ac-AK+H $)^{2+},(\text { DMAP-ac-KA+H) })^{2+},(\text { pyrid-ac-AK }+\mathrm{H})^{2+}$ and (pyridac-KA+H $)^{2+}$ ions, as well as underivatized $(\mathbf{A K}+2 \mathrm{H})^{2+}$, completely dissociated. The fixed-charge tags steered the dissociation upon electron transfer to form abundant backbone $\mathrm{N}-\mathrm{C}_{\alpha}$ bond cleavages, whereas the underivatized peptide mainly underwent $\mathrm{H}$-atom and side-chain losses. Precursor ion structures for the tagged peptides were analyzed by an exhaustive conformational search combined with $\mathrm{B} 3 \mathrm{LYP} / 6-31+\mathrm{G}(\mathrm{d}, \mathrm{p})$ geometry optimization and single-point energy calculations in order to select the global energy minima. Structures, relative energies, transition states, ion-molecule complexes, and dissociation products were identified for several chargereduced species from the tagged peptides. The electronic properties of the charge tags and their interactions with the peptide moieties are discussed. Electrospray ionization and electrontransfer dissociation of larger peptides are illustrated with a DMAP-tagged pentapeptide.
\end{abstract}

Key words: Fixed-charge tags, Peptide derivatization, Electron-transfer dissociation, Ion structures, Ab initio calculations

\section{Introduction}

G lectron-transfer dissociation (ETD) is one of the newer

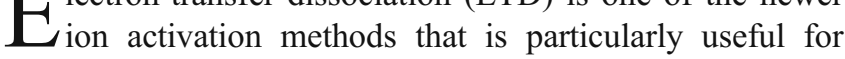

Thomas W. Chung and Christopher L. Moss contributed equally to this work.

Electronic supplementary material The online version of this article (doi:10.1007/s13361-010-0012-9) contains supplementary material, which is available to authorized users.

Correspondence to: František Tureček; e-mail: turecek@chem.washington.edu peptide sequencing [1]. In typical ETD experiments, multiply protonated peptides are produced by electrospray ionization, stored in a radiofrequency ion trap, and partially discharged by electron transfer from a molecular anion donor. Another experimental technique, called electroncapture-induced dissociation (ECID [2]), makes use of fast ion beams that are partially discharged by collisional electron transfer from gaseous alkali metal atoms. A common feature of ETD and ECID is that charge-reduced peptide ions undergo dissociations through the loss of 
hydrogen atoms, ammonia, amino acid side chains, and backbone $\mathrm{N}-\mathrm{C}_{\alpha}$ bond cleavages. The latter afford sequence fragments containing the N-terminal residues (even-electron c-type ions) and those containing C-terminal residues (oddelectron z-type ions).

The mechanism of $\mathrm{N}-\mathrm{C}_{\alpha}$ bond cleavage has been of intense interest, especially regarding its dependence on the nature and sequence of amino acid residues [3-6], precursor ion charge state [7-9], and peptide secondary structure [1014]. One of the questions that has been addressed by experiment [3] and theory [15] was the nature and position of charge sites in peptide ions and their effects on electronbased dissociations. The position of the charge site can be established by incorporating highly basic arginine residues into model peptides that provide unequivocal protonation sites [16]. However, a more general approach is to derivatize in situ the desired peptide with a charge-carrying or readily ionizable group [17-24], and thus affix the charge position in the sequence. Various charge tags have been implemented on an ad hoc basis of availability and convenience, such as 2,4,6-trimethylpyridinium [25], 2,2'-bipyridyl [26], tris (2,4,6-trimethoxyphenyl)phosphonium [24, 27-29], trimethylammoniumalkyl [30], etc. The charge tags function as potential electron attachment sites, depending on their intrinsic recombination energies (REs) relative to those of the charged peptide residue [31]. We have analyzed through computation fixed-charge pyridinium tags in which the intrinsic RE could be varied by selecting ring substituents (R) [31]. The REs ranged from $5.65 \mathrm{eV}$ for electronwithdrawing groups $(\mathrm{R}=\mathrm{CN})$, through $5.03 \mathrm{eV}$ for unsubstituted pyridinium $(\mathrm{R}=\mathrm{H})$, to $4.10 \mathrm{eV}$ for electrondonating groups $\left(\mathrm{R}=\mathrm{N}\left(\mathrm{CH}_{3}\right)_{2}\right)$ (Scheme 1).

Molecular orbital analysis of small peptides that were tagged with pyridinium groups indicated that the 4-dimethylaminopyridinium tag had the most extensive interaction between the ring and peptide $\pi^{*}$-molecular orbitals due to the closest match of the corresponding recombination energies [32]. According to the current mechanisms of electron-based peptide dissociations, the so-called UtahWashington (UW) model [33] postulates that amide $\pi^{*}$ orbitals play a crucial role in $\mathrm{N}-\mathrm{C}_{\alpha}$ bond cleavage [34, 35]. It was therefore of interest to investigate by experiment and electron structure theory the behavior of model chargetagged peptide ions. To make the models amenable to both experiment and high-level computational analysis, we selected Ala-Lys (AK) and Lys-Ala (KA) dipeptides that were tagged at the N-termini by N-pyridiniummethylcarbonyl and $\mathrm{N}$-(4-dimethylaminopyridinium)methylcarbonyl groups (Scheme 1). We now report high-resolution ETD mass spectra of doubly charged ions carrying these tags. We wish to show that the charge tags substantially enhance backbone $\mathrm{N}-\mathrm{C}_{\alpha}$ bond dissociations compared to underivatized peptides. We also report a detailed analysis of the energetics and mechanisms of peptide cation-radical dissociations that was performed at high levels of ab initio theory. The results of this pilot study will be used for a comprehensive investigation of electron-based dissociations of a large set of charge-tagged peptides. An example of the charge tagging and ETD of a pentapeptide of a tryptic type is reported here.

\section{Experimental}

\section{Materials and Methods}

The fixed-charge tagged dipeptides pyrid-ac-AK $(93 \%$ pure), pyrid-ac-KA ( $99 \%$ pure), DMAP-ac-AK ( $97 \%$ pure), and DMAP-ac-KA ( $96 \%$ pure) were custom synthesized by PolyPeptide Laboratories (Strasbourg, France) and used as received. Alternatively, the following in-house developed preparative procedure can be used for DMAP derivatives. A peptide solution $[100 \mu 1$ of $3 \mathrm{mM}$ peptide solution in acetonitrile/water $(1 / 1 \mathrm{v} / \mathrm{v})]$ and $300 \mu 1$ of $30 \mathrm{mM}$ triethylamine in water were mixed with $100 \mu \mathrm{l}$ of $12 \mathrm{mM} \mathrm{N}$ hydroxysuccinimidyl iodoacetate (ProChem, Inc., Rockford, IL, USA, catalog no. CL214) on a vortex mixer for $10 \mathrm{~min}$. Then $50 \mu \mathrm{l}$ of a $120 \mathrm{mM}$ 4-(dimethylamino)pyridine (Sigma-Aldrich, St. Louis, MO, USA, catalog no. 522805$5 \mathrm{G})$ solution in acetonitrile was added, and the resulting mixture was stirred at $75^{\circ} \mathrm{C}$ for $2 \mathrm{~h}$. The solution was then diluted with acetonitrile/water/acetic acid (48.5/48.5/1) to a concentration of $10 \mu \mathrm{M}$ and used without further purification
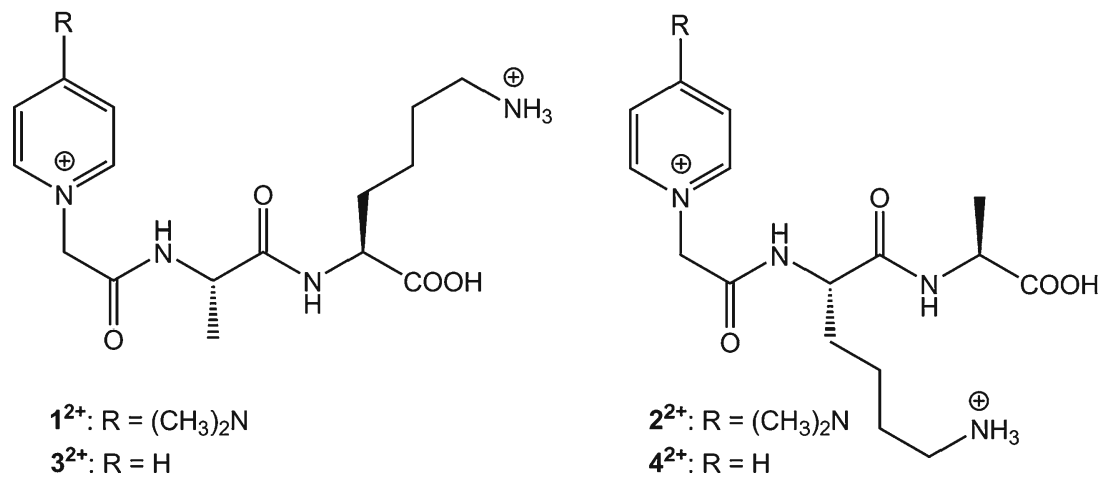

Scheme 1. Charge-tagged $A K$ and KA peptide ions 
for direct infusion using the electrospray ion source of a mass spectrometer to afford abundant doubly charged ions.

Electron-transfer dissociation mass spectra were measured on a Thermo Fisher (San Jose, CA, USA) LTQ Orbitrap Velos hybrid mass spectrometer and an LTQ XL linear ion trap instrument, both outfitted with a chemical ionization source for the production of fluoranthene anion radials as ETD reagent. Precursor dications were mass isolated with a window of $3-4 \mathrm{~m} / \mathrm{z}$ units to accommodate the nearest ${ }^{13} \mathrm{C}$ isotopologs and allowed to react for 100 and $200 \mathrm{~ms}$ with fluoranthene anions. Electron-capture dissociation (ECD) mass spectra were obtained on a Thermo Fisher LTQ-FT-ICR instrument. Precursor ions were isolated in the LTQ with a mass-selection window of $1.8-2.5 \mathrm{~m} / \mathrm{z}$ units, transferred to the ion cyclotron resonance (ICR) cell, and irradiated by electrons from an external source. The electron energy could not be measured directly, and the corresponding electron emitter bias was set at $3 \mathrm{~V}$, which provided the best ECD efficiency. The irradiation pulse width was $300 \mathrm{~ms}$.

\section{Calculations}

\section{Conformational Search and Quantum Chemistry Calculations}

Our strategy for finding the lowest energy conformations is to first generate a large number of candidate structures in the molecular dynamics regime, then refine the relative energies and re-optimize geometries with semi-empirical and ab initio methods. Molecular dynamics calculations were performed using NAMD [36]. Semi-empirical and ab initio calculations were performed using Gaussian 09 [37].

Molecular dynamics force-field parameters have not previously been developed for charge-tagged residues. We obtained charge distributions and force constants with ab initio calculations in order to develop a set of parameters for the charge tags. This parameter set is not intended to be sufficiently characterized to accurately reproduce all thermodynamic properties, but merely to be accurate enough to generate qualitatively reasonable candidate structures. Other residues are parameterized using established values from the CHARMM force field [38].

Once the force-field parameters have been determined, replica exchange molecular dynamics (REMD) [39] are performed on each sequence. Calculations are run for $10 \mathrm{~ns}$ with a step size of $1 \mathrm{fs}$ with eight temperature replicas from 300 to $800 \mathrm{~K}$. One thousand structures from each replica are selected at regular intervals for a total of 8000 initial candidate structures. Each candidate structure is then optimized at the PM6 level [40]. The PM6-optimized structures are then analyzed for potential hydrogen bonds. Structures with the same hydrogen bonds are grouped together and the lowest energy structure from each group is taken to form a new list of candidate structures. The single point energy for each candidate structure is calculated at the
B3LYP/6-31+G(d,p) level [41-43], and the structures from each sequence with the lowest energy are re-optimized at the same level and the local minimum confirmed with frequency calculation. B3LYP/6-311++G(2d,p) and MP2/6-311++G $(2 \mathrm{~d}, \mathrm{p})$ [44] single point energies are calculated for each reoptimized structure. The energies calculated from each of these methods were averaged to cancel known errors in each method [45]. Calculations of radical states began with the optimized dication structures. Time-dependent density functional theory [46] (TD-DFT) was used to calculate the first 15 excited states of the vertically attached radical configuration at B3LYP/6-311++G(2d,p). Selected structures were re-optimized with the charge-reduced electronic configuration at the B3LYP/6-31+G(d,p) level, and the structures were confirmed as local minima or first-order saddle points by harmonic frequency calculations. Single point energies were calculated with B3LYP/6-311++G(2d,p) and spinprojected MP2/6-311++G(2d,p) and averaged to provide improved relative energies for cation radicals.

\section{Results}

Electrospray of the fixed-charge tagged peptides gave abundant dications (DMAP-ac-AK $+\mathrm{H})^{2+}\left(\mathbf{1}^{\mathbf{2 +}}\right)$, (DMAP-ac$\mathbf{K A}+\mathrm{H})^{2+}\left(\mathbf{2}^{\mathbf{2 +}}\right)$, (pyrid-ac-AK+H$)^{2+}\left(\mathbf{3}^{\mathbf{2 +}}\right)$, and (pyrid-ac-KA $+\mathrm{H})^{2+}\left(4^{2+}\right)$. All precursor and fragment ions were characterized by accurate mass measurements to ascertain their elemental compositions and those of the neutral fragments. The accurate $m / z$ values are listed in Table 1. For backbone fragments, we use the standard nomenclature $[47,48]$ that was adapted for the presence of the N-terminal tag, which is considered a pseudo-residue. Fragment ions corresponding by their elemental composition to the tag plus amide are denoted as $\boldsymbol{c}_{\mathbf{0}}$.

\section{Electron Transfer to DMAP-ac-AK/KA and pyrid- ac-AK/KA Ions}

The ETD spectra measured on the Velos-Orbitrap and LTQ instruments showed essentially the same fragment ions. The Velos Orbitrap ETD mass spectra are shown in Figure 1. The LTQ ETD mass spectra are given in Figure S1 of the Electronic Supplementary Material (ESM). Both types of ETD spectra showed no charge-reduced ions for $\mathbf{1}^{\mathbf{2 +}}-\mathbf{4}^{\mathbf{2 +}}$. This was unequivocally established by accurate mass measurements at the corresponding $\mathrm{m} / \mathrm{z} 381$ for the DMAP-tagged peptides and $\mathrm{m} / \mathrm{z} 338$ for the pyrid-tagged ones, which showed only baseline-resolved ${ }^{15} \mathrm{~N}$ and ${ }^{13} \mathrm{C}$ isotope satellites of the respective abundant $\mathrm{m} / \mathrm{z} 380$ and $\mathrm{m} / \mathrm{z}$ 337 ions (Table 1). Hence, the loss of an $\mathrm{H}$ atom was a major dissociation upon electron transfer to all our chargetagged peptide ions.

The ETD mass spectrum of $\mathbf{1}^{\mathbf{2 +}}$ (Figure 1a) showed major backbone fragments at $\mathrm{m} / \mathrm{z} 251\left(\boldsymbol{c}_{\mathbf{1}}\right)$ and $\mathrm{m} / \mathrm{z} 180\left(\boldsymbol{c}_{\mathbf{0}}\right)$, resulting from $\mathrm{N}-\mathrm{C}_{\alpha}$ bond cleavage and charge retention in 
Table 1. Accurate ion $m / z$ values in ETD and ECD mass spectra

\begin{tabular}{|c|c|c|c|c|}
\hline Peptide ion & ETD & ECD & El. composition & Calc. \\
\hline $1^{2+}$ & $\begin{array}{l}- \\
381.2323 \\
381.2259 \\
380.2289 \\
366.2133 \\
259.1526 \\
252.1342 \\
251.1502 \\
- \\
- \\
190.6182 \\
180.1130 \\
- \\
- \\
123.0916\end{array}$ & $\begin{array}{l}- \\
- \\
- \\
380.2287 \\
- \\
- \\
252.1338 \\
251.1498 \\
234.1233 \\
206.1284 \\
190.6179 \\
180.1128 \\
163.0863 \\
149.0706 \\
123.0914 \\
84.0806\end{array}$ & $\begin{array}{l}\mathrm{C}_{18} \mathrm{H}_{31} \mathrm{~N}_{5} \mathrm{O}_{4} \\
\left({ }^{13} \mathrm{C} \mathrm{C}_{17} \mathrm{H}_{30} \mathrm{~N}_{5} \mathrm{O}_{4}\right. \\
\mathrm{C}_{18} \mathrm{H}_{30}\left({ }^{15} \mathrm{~N} \mathrm{~N}_{4} \mathrm{O}_{4}\right. \\
\mathrm{C}_{18} \mathrm{H}_{30} \mathrm{~N}_{5} \mathrm{O}_{4} \\
\mathrm{C}_{17} \mathrm{H}_{28} \mathrm{~N}_{5} \mathrm{O}_{4} \\
\mathrm{C}_{11} \mathrm{H}_{21} \mathrm{~N}_{3} \mathrm{O}_{4} \\
\mathrm{C}_{12} \mathrm{H}_{18} \mathrm{~N}_{3} \mathrm{O}_{3} \\
\mathrm{C}_{12} \mathrm{H}_{19} \mathrm{~N}_{4} \mathrm{O}_{2} \\
\mathrm{C}_{12} \mathrm{H}_{16} \mathrm{~N}_{3} \mathrm{O}_{2} \\
\mathrm{C}_{11} \mathrm{H}_{16} \mathrm{~N}_{3} \mathrm{O} \\
\mathrm{C}_{18} \mathrm{H}_{31} \mathrm{~N}_{5} \mathrm{O}_{4}{ }^{2+} \\
\mathrm{C}_{9} \mathrm{H}_{14} \mathrm{~N}_{3} \mathrm{O} \\
\mathrm{C}_{9} \mathrm{H}_{11} \mathrm{~N}_{2} \mathrm{O} \\
\mathrm{C}_{8} \mathrm{H}_{9} \mathrm{~N}_{2} \mathrm{O} \\
\mathrm{C}_{7} \mathrm{H}_{11} \mathrm{~N}_{2} \\
\mathrm{C}_{5} \mathrm{H}_{10} \mathrm{~N}\end{array}$ & $\begin{array}{r}381.2376 \\
381.2331 \\
381.2268 \\
380.2298 \\
366.2141 \\
259.1532 \\
252.1348 \\
251.1508 \\
234.1242 \\
206.1293 \\
190.6188 \\
180.1137 \\
163.0871 \\
149.0715 \\
123.0922 \\
84.0813\end{array}$ \\
\hline $2^{2+}$ & $\begin{array}{l}381.2324 \\
381.2260 \\
380.2290 \\
366.2135 \\
308.2080 \\
\\
259.1527 \\
190.6182 \\
180.1131 \\
- \\
123.0916\end{array}$ & $\begin{array}{l}- \\
- \\
380.2287 \\
- \\
- \\
291.1811 \\
- \\
190.6179 \\
180.1128 \\
163.0863 \\
149.0707 \\
123.0914 \\
84.0806\end{array}$ & $\begin{array}{l}\left({ }^{13} \mathrm{C}\right) \mathrm{C}_{17} \mathrm{H}_{30} \mathrm{~N}_{5} \mathrm{O}_{4} \\
\mathrm{C}_{18} \mathrm{H}_{30}\left({ }^{15} \mathrm{~N}\right) \mathrm{N}_{4} \mathrm{O}_{4} \\
\mathrm{C}_{18} \mathrm{H}_{30} \mathrm{~N}_{5} \mathrm{O}_{4} \\
\mathrm{C}_{17} \mathrm{H}_{28} \mathrm{~N}_{5} \mathrm{O}_{4} \\
\mathrm{C}_{15} \mathrm{H}_{26} \mathrm{~N}_{5} \mathrm{O}_{2} \\
\mathrm{C}_{15} \mathrm{H}_{23} \mathrm{~N}_{4} \mathrm{O}_{2} \\
\mathrm{C}_{11} \mathrm{H}_{21} \mathrm{O}_{4} \mathrm{~N}_{3} \\
\mathrm{C}_{18} \mathrm{H}_{31} \mathrm{~N}_{5} \mathrm{O}_{4}{ }^{2+} \\
\mathrm{C}_{9} \mathrm{H}_{14} \mathrm{~N}_{3} \mathrm{O} \\
\mathrm{C}_{9} \mathrm{H}_{11} \mathrm{~N}_{2} \mathrm{O} \\
\mathrm{C}_{8} \mathrm{H}_{9} \mathrm{~N}_{2} \mathrm{O} \\
\mathrm{C}_{7} \mathrm{H}_{11} \mathrm{~N}_{2} \\
\mathrm{C}_{5} \mathrm{H}_{10} \mathrm{~N}\end{array}$ & $\begin{array}{r}381.2331 \\
381.2268 \\
380.2298 \\
366.2141 \\
308.2086 \\
291.1821 \\
259.1532 \\
190.6188 \\
180.1129 \\
163.0871 \\
149.0715 \\
123.0922 \\
84.0813\end{array}$ \\
\hline $3^{2+}$ & $\begin{array}{l}- \\
338.1902 \\
338.1838 \\
337.1868 \\
320.1603 \\
259.1526 \\
241.1421 \\
- \\
216.1342 \\
209.0920 \\
208.1080 \\
\\
169.0971 \\
163.0866 \\
147.1128 \\
137.0709 \\
131.0940 \\
- \\
84.0808 \\
-\end{array}$ & $\begin{array}{l}- \\
- \\
- \\
337.1874 \\
- \\
- \\
240.1344 \\
- \\
209.0920 \\
\\
191.0814 \\
169.0970 \\
163.0865 \\
147.1127 \\
137.0708 \\
131.0940 \\
120.0443 \\
84.0807 \\
80.0494\end{array}$ & $\begin{array}{l}\mathrm{C}_{16} \mathrm{H}_{26} \mathrm{~N}_{4} \mathrm{O}_{4} \\
\left({ }_{13} \mathrm{C} \mathrm{C}_{15} \mathrm{H}_{25} \mathrm{~N}_{4} \mathrm{O}_{4}\right. \\
\mathrm{C}_{16} \mathrm{H}_{25}\left({ }^{15} \mathrm{~N} \mathrm{~N}_{3} \mathrm{O}_{4}\right. \\
\mathrm{C}_{16} \mathrm{H}_{25} \mathrm{~N}_{4} \mathrm{O}_{4} \\
\mathrm{C}_{16} \mathrm{H}_{22} \mathrm{~N}_{3} \mathrm{O}_{4} \\
\mathrm{C}_{11} \mathrm{H}_{21} \mathrm{~N}_{3} \mathrm{O}_{4} \\
\mathrm{C}_{11} \mathrm{H}_{19} \mathrm{~N}_{3} \mathrm{O}_{3} \\
\mathrm{C}_{11} \mathrm{H}_{18} \mathrm{~N}_{3} \mathrm{O}_{3} \\
\mathrm{C}_{9} \mathrm{H}_{18} \mathrm{~N}_{3} \mathrm{O}_{3} \\
\mathrm{C}_{10} \mathrm{H}_{13} \mathrm{~N}_{2} \mathrm{O}_{3} \\
\mathrm{C}_{10} \mathrm{H}_{14} \mathrm{~N}_{3} \mathrm{O}_{2} \\
\mathrm{C}_{10} \mathrm{H}_{11} \mathrm{~N}_{2} \mathrm{O}_{2} \\
\mathrm{C}_{16} \mathrm{H}_{26} \mathrm{~N}_{4} \mathrm{O}_{4}{ }^{2+} \\
\mathrm{C}_{9} \mathrm{H}_{11} \mathrm{~N}_{2} \mathrm{O} \\
\mathrm{C}_{6} \mathrm{H}_{15} \mathrm{~N}_{2} \mathrm{O}_{2} \\
\mathrm{C}_{7} \mathrm{H}_{9} \mathrm{~N}_{2} \mathrm{O} \\
\mathrm{C}_{6} \mathrm{H}_{13} \mathrm{NO}_{2} \\
\mathrm{C}_{7} \mathrm{H}_{6} \mathrm{NO} \\
\mathrm{C}_{5} \mathrm{H}_{10} \mathrm{~N} \\
\mathrm{C}_{5} \mathrm{H}_{6} \mathrm{~N}\end{array}$ & $\begin{array}{r}338.1954 \\
338.1909 \\
338.1846 \\
337.1876 \\
320.1610 \\
259.1532 \\
241.1426 \\
240.1348 \\
216.1348 \\
209.0926 \\
208.1086 \\
191.0821 \\
169.0977 \\
163.0871 \\
147.1134 \\
137.0715 \\
131.0946 \\
120.0449 \\
84.0813 \\
80.0500\end{array}$ \\
\hline $4^{2+}$ & $\begin{array}{l}338.1902 \\
338.1837 \\
337.1868 \\
320.1603 \\
266.1498 \\
265.1658 \\
259.1526 \\
248.1393 \\
241.1420 \\
- \\
- \\
199.1077 \\
169.0971 \\
143.1178 \\
137.0709 \\
120.0443\end{array}$ & $\begin{array}{l}- \\
337.1873 \\
- \\
266.1500 \\
- \\
- \\
248.1394 \\
- \\
240.1343 \\
209.0920 \\
199.1076 \\
169.0970 \\
- \\
137.0708 \\
120.0442 \\
90.0548 \\
84.0807 \\
80.0494\end{array}$ & $\begin{array}{l}\left({ }^{13} \mathrm{C}\right) \mathrm{C}_{15} \mathrm{H}_{25} \mathrm{~N}_{4} \mathrm{O}_{4} \\
\mathrm{C}_{16} \mathrm{H}_{25}\left({ }^{15} \mathrm{~N}\right) \mathrm{N}_{3} \mathrm{O}_{4} \\
\mathrm{C}_{16} \mathrm{H}_{25} \mathrm{~N}_{4} \mathrm{O}_{4} \\
\mathrm{C}_{16} \mathrm{H}_{22} \mathrm{~N}_{3} \mathrm{O}_{4} \\
\mathrm{C}_{13} \mathrm{H}_{20} \mathrm{~N}_{3} \mathrm{O}_{3} \\
\mathrm{C}_{13} \mathrm{H}_{21} \mathrm{~N}_{4} \mathrm{O}_{2} \\
\mathrm{C}_{11} \mathrm{H}_{21} \mathrm{~N}_{3} \mathrm{O}_{4} \\
\mathrm{C}_{13} \mathrm{H}_{18} \mathrm{~N}_{3} \mathrm{O}_{2} \\
\mathrm{C}_{11} \mathrm{H}_{19} \mathrm{~N}_{3} \mathrm{O}_{3} \\
\mathrm{C}_{11} \mathrm{H}_{18} \mathrm{~N}_{3} \mathrm{O}_{3} \\
\mathrm{C}_{10} \mathrm{H}_{13} \mathrm{~N}_{2} \mathrm{O}_{3} \\
\mathrm{C}_{9} \mathrm{H}_{15} \mathrm{~N}_{2} \mathrm{O}_{3} \\
\mathrm{C}_{16} \mathrm{H}_{26} \mathrm{~N}_{4} \mathrm{O}_{4}{ }^{2+} \\
\mathrm{C}_{7} \mathrm{H}_{15} \mathrm{~N}_{2} \mathrm{O} \\
\mathrm{C}_{7} \mathrm{H}_{9} \mathrm{~N}_{2} \mathrm{O} \\
\mathrm{C}_{7} \mathrm{H}_{6} \mathrm{NO} \mathrm{NO}_{3} \mathrm{H}_{8} \mathrm{NO}_{2} \\
\mathrm{C}_{5} \mathrm{H}_{10} \mathrm{~N} \\
\mathrm{C}_{5} \mathrm{H}_{6} \mathrm{~N}\end{array}$ & $\begin{array}{r}338.1909 \\
338.1846 \\
337.1876 \\
320.1610 \\
266.1505 \\
265.1665 \\
259.1532 \\
248.1399 \\
241.1426 \\
240.1348 \\
209.0926 \\
199.1083 \\
169.0977 \\
143.1184 \\
137.0715 \\
120.0449 \\
90.0555 \\
84.0813 \\
80.0500\end{array}$ \\
\hline
\end{tabular}



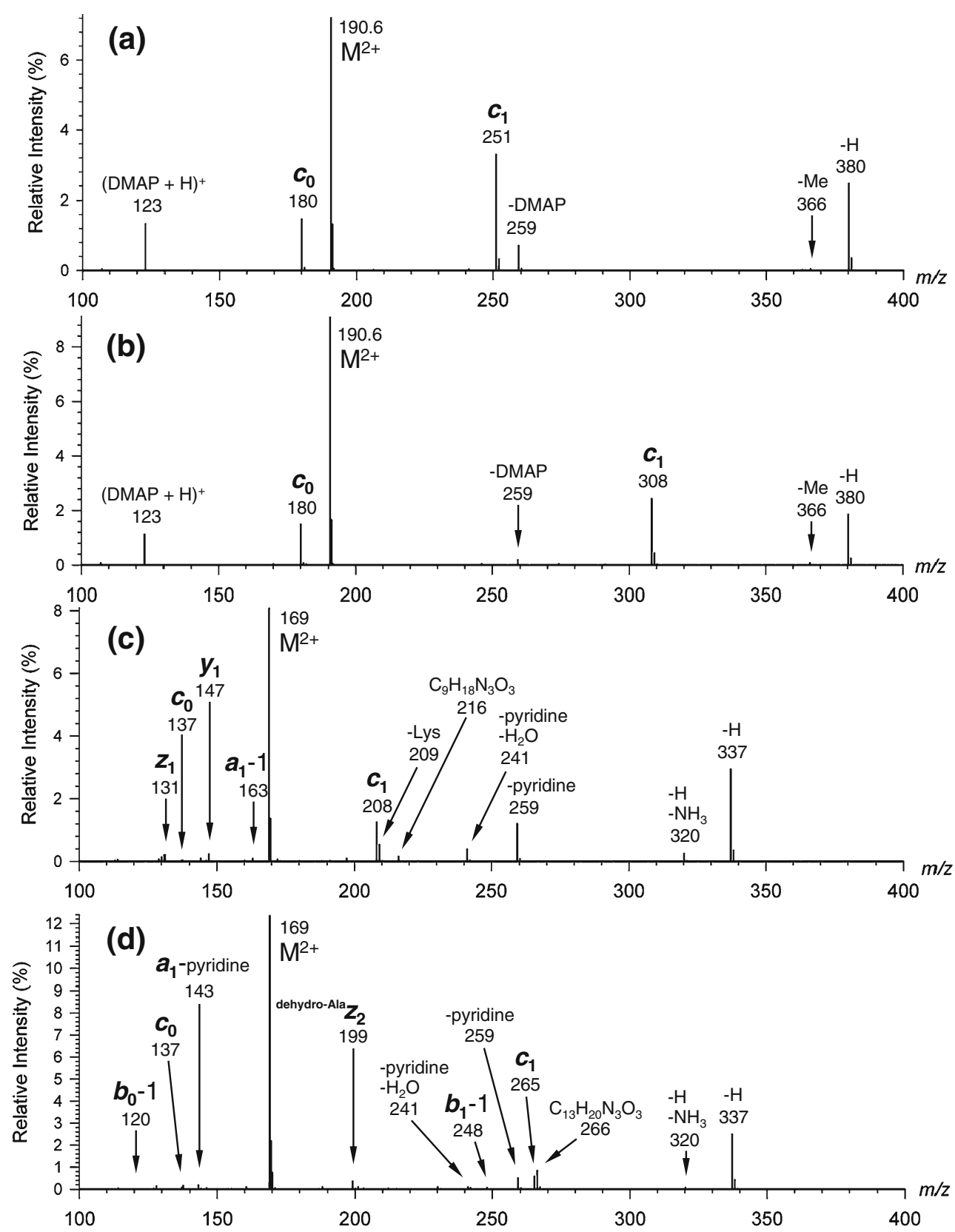

Figure 1. ETD mass spectra of doubly charged ions from (a) DMAP-ac-AK $\left(\mathbf{1}^{2+}\right)$, (b) DMAP-ac-KA $\left(2^{2+}\right)$, (c) pyrid-ac-AK $\left(3^{2+}\right)$, and (d) pyrid-ac-KA $\left(4^{2+}\right)$ collected on a hybrid LTQ Orbitrap Velos instrument. Relative intensities are given as percentages of the sum of the charge-reduced ion intensities

the tag. In addition, a competing $\mathrm{N}-\mathrm{C}_{\alpha}$ bond cleavage at the DMAP moiety gave rise to fragments at $\mathrm{m} / \mathrm{z} 259$ and 123 , the latter corresponding to protonated 4-dimethylaminopyridine. Note that these are complementary ions that differ in the position of the charging proton. The greater relative abundance of the $(\mathrm{DMAP}+\mathrm{H})^{+}$ion indicates that DMAP is more basic than the ${ }^{\circ} \mathrm{CH}_{2} \mathrm{CO}$-Ala-Lys dipeptide residue.

The ETD mass spectrum of $\mathbf{2}^{\mathbf{2 +}}$ (Figure 1 b) was quite analogous to that of $\mathbf{1}^{\mathbf{2 +}}$ in showing the $\boldsymbol{c}_{\mathbf{1}}(\mathrm{m} / \mathrm{z} 308)$ and $\boldsymbol{c}_{\mathbf{0}}(\mathrm{m} / \mathrm{z}$ $180)$ backbone fragments, as well as those due to the tag loss. Note that the tag loss peak $(m / z 259)$ was substantially weaker from $\mathbf{2}^{\mathbf{2 +}}$ than from $\mathbf{1}^{\mathbf{2 +}}$. The general appearance of the ETD spectra of the DMAP-tagged peptides was that they were very clean and showed practically no fragments from side-chain losses or consecutive dissociations.

The ETD spectra of $\mathbf{3}^{2+}$ and $\mathbf{4}^{\mathbf{2 +}}$ showed the $c_{\mathbf{1}}$ backbone fragments at $\mathrm{m} / \mathrm{z} 208$ and 265, respectively, whereas the $\boldsymbol{c}_{\mathbf{0}}$ ion at $m / z 137$ was very weak. Loss of the tag $(m / z 259)$ was more pronounced for $\mathbf{3}^{2+}$. A few additional sequence fragments were found, such as the $\boldsymbol{y}_{\mathbf{1}}$ ion at $\mathrm{m} / z 147$ from $3^{2+}$ and the $m / z 266$ ion from $4^{2+}$. According to the accurate mass measurements (Table 1), the $m / z 266$ fragment arises 
through the elimination of an alanine residue $\left(\mathrm{C}_{3} \mathrm{H}_{5} \mathrm{NO}\right)$ from the $\mathrm{m} / \mathrm{z} 337$ ion, and must involve a carboxyl $\mathrm{OH}$ group migration.

We also attempted to obtain ETD mass spectra of nonderivatized $(\mathrm{AK}+2 \mathrm{H})^{2+}$ and $(\mathrm{KA}+2 \mathrm{H})^{2+}$ ions. The $\mathrm{AK}$ peptide provided doubly charged precursor ions with intensities that were sufficient for ETD measurements. However, the ETD spectrum showed a very poor yield for charge reduction, even at prolonged ion-ion interaction times (Figure S2 of the ESM). The fragmentations observed upon electron transfer were the loss of $\mathrm{H}(\mathrm{m} / \mathrm{z} 218)$ followed by the elimination of ammonia $(\mathrm{m} / \mathrm{z} 201)$ and water $(\mathrm{m} / \mathrm{z}$ 200 ), and backbone cleavage giving the $\boldsymbol{y}_{\mathbf{1}}$ ion at $\mathrm{m} / z 147$ and its further dissociation products at $\mathrm{m} / z$ 130, 129, 114, and 100 . The KA peptide produced mainly singly charged ions, so ETD was not performed.

\section{Electron Transfer to Larger Tagged Peptides}

Tagging with DMAP was also investigated for larger peptides that may be more relevant to analytical applications of ETD in peptide sequencing. Although a critical evaluation of the procedure and its benefits and drawbacks when applied to a large number of tryptic peptides is beyond the scope of this report, encouraging results were obtained for pentapeptides of a tryptic type, as illustrated with AAAHR. Figure 2a shows the electrospray mass spectrum of the reaction mixture directly after tagging and without any purification. The mass spectrum is dominated by a triply charged ion of (DMAP-AAAHR $+2 \mathrm{H})^{3+}$, whereas the peak of the unreacted peptide $(\mathrm{m} / \mathrm{z}$ 263.2) is weak, indicating good conversion. The ETD spectrum of the triply charged ion (Figure $2 \mathrm{~b}$ ) shows complete series of $\boldsymbol{c}_{1}-\boldsymbol{c}_{4}$ as well as $\boldsymbol{z}_{1}{ }^{-}$ $z_{4}$ ions. A notable feature is the very low relative intensities of sequence $c-1$ and $z+1$ fragment ions that underwent hydrogen atom transfer. This contrasts with the ETD spectrum of the doubly charged ion from untagged AAAHR (Figure 2c), which shows only $\boldsymbol{z}$ ions, some of which are accompanied by $z^{+1}$ satellites (e.g., for the $z_{1}$ and $z_{3}$ fragments). Thus, tagging with DMAP increases the charge state of peptide ions to make them suitable for ETD, and improves sequence coverage by providing fragment ions from both the $\mathrm{N}$ and $\mathrm{C}$ termini.

\section{Electron Capture by DMAP-ac-AK/KA and pyrid-ac- $A K / K A$ Ions}

To compare different modes of charge reduction, the electron-capture dissociation (ECD) [49] mass spectra were also recorded. Figure 3 shows that the ECD spectra are very different from the ETD spectra in Figure 1. In particular, the ECD spectrum of $\mathbf{1}^{\mathbf{2 +}}$ (Figure 3a) showed a very weak $\mathrm{m} / \mathrm{z}$ 380 fragment ion from the loss of $\mathrm{H}$ from the chargereduced ion, which was absent. Major fragments were observed at $\mathrm{m} / z 252,234$, and 206, which corresponded to elimination of the lysine residue $\left(\mathrm{C}_{6} \mathrm{H}_{12} \mathrm{~N}_{2} \mathrm{O}\right)$ from the $\mathrm{m} / \mathrm{z}$
380 ion, followed by elimination of water and $\mathrm{H}_{2} \mathrm{CO}_{2}$. These fragments indicate that this dissociation commences by a carboxyl $\mathrm{OH}$ group migration from the Lys to the Ala residue. The $c_{\mathbf{1}}$ fragment at $\mathrm{m} / \mathrm{z} 251$ is very weak, whereas the $c_{0}$ fragment at $m / z 180$ and its dissociation product at $\mathrm{m} / \mathrm{z}$ 163 by loss of ammonia are relatively abundant. Fragmentation at the $\mathrm{N}$-terminus forms the (DMAP $+\mathrm{H})^{+}$ion at $\mathrm{m} / \mathrm{z}$ 123, whereas the complementary $\mathrm{m} / z 259$ ion is absent. The ECD spectrum of $\mathbf{2}^{\mathbf{2 +}}$ (Figure $3 \mathrm{~b}$ ) is analogous to that of $\mathbf{1}^{\mathbf{2 +}}$. The spectrum in Figure $3 \mathrm{~b}$ shows a weak $m / z 380$ ion that eliminates alanine $\left(\mathrm{C}_{3} \mathrm{H}_{7} \mathrm{NO}_{2}\right)$ to give the $\mathrm{m} / z 291$ fragment. The other fragments are $c_{\mathbf{0}}(\mathrm{m} / z \mathrm{1} 180)$ and its dissociation products $(\mathrm{m} / \mathrm{z} 163$ and 149$)$, as well as the $\mathrm{C}_{5} \mathrm{H}_{10} \mathrm{~N}^{+}$ion at $\mathrm{m} / \mathrm{z} 84$ from the lysine side chain.

The ECD spectra of $\mathbf{3}^{\mathbf{2 +}}$ and $\mathbf{4}^{\mathbf{2 +}}$ showed extremely weak $\mathrm{m} / \mathrm{z} 337$ ions by charge reduction and loss of an $\mathrm{H}$ atom. This was followed by loss of the C-terminal residue, $m / z 209$ and $m / z 266$ for loss of lysine and $\mathrm{C}_{3} \mathrm{H}_{5} \mathrm{O}$, respectively, and the subsequent elimination of the remaining amino acid to give the common pyridiniumketene fragment at $\mathrm{m} / \mathrm{z} 120$. Other common ECD fragments were $\mathrm{C}_{5} \mathrm{H}_{10} \mathrm{~N}^{+}(m / z$ 84) from the lysine side chain and protonated pyridine $(\mathrm{m} / \mathrm{z} 80)$.

The differences between the ECD and ETD mass spectra of peptide ions are currently not well understood, but may be due to different electronic states accessed upon the capture of a free electron in ECD and the transfer of an electron from an anionic donor in ETD [50]. An obvious difference is the energetics of ECD and ETD, as discussed below.

\section{Discussion}

The ETD and ECD mass spectra showed that both the nature of the fixed-charge tag and the mode of charge reduction had substantial effects on the dissociations. From the point of view of ETD efficiency, the fixed-charge tags substantially improved double charging of dipeptides and triple charging of pentapeptides and provided abundant precursor ions. Thus, pyridinium-based charge tags are expected to have a favorable effect on the formation of multiply charged ions from larger peptides, especially those that do not contain basic amino acid residues. From the point of view of sequence information, ETD of the DMAP-tagged peptides appeared to be the most informative, and therefore we focused on interpreting the spectra of $\mathbf{1}^{\mathbf{2 +}}$ and $\mathbf{2}^{\mathbf{2 +}}$. The interpretation starts with precursor ion structures, which are discussed next.

\section{Precursor Ion Structures of DMAP-ac-AK/KA}

The tautomers we considered for both charge-tagged peptides were protonated in the lysine $\varepsilon$-amino group, which corresponded to the most basic site in the dipeptides [15]. An extensive search of the dication conformational potential energy surface (PES) revealed several structures for $\mathbf{1}^{\mathbf{2 +}}$ and 

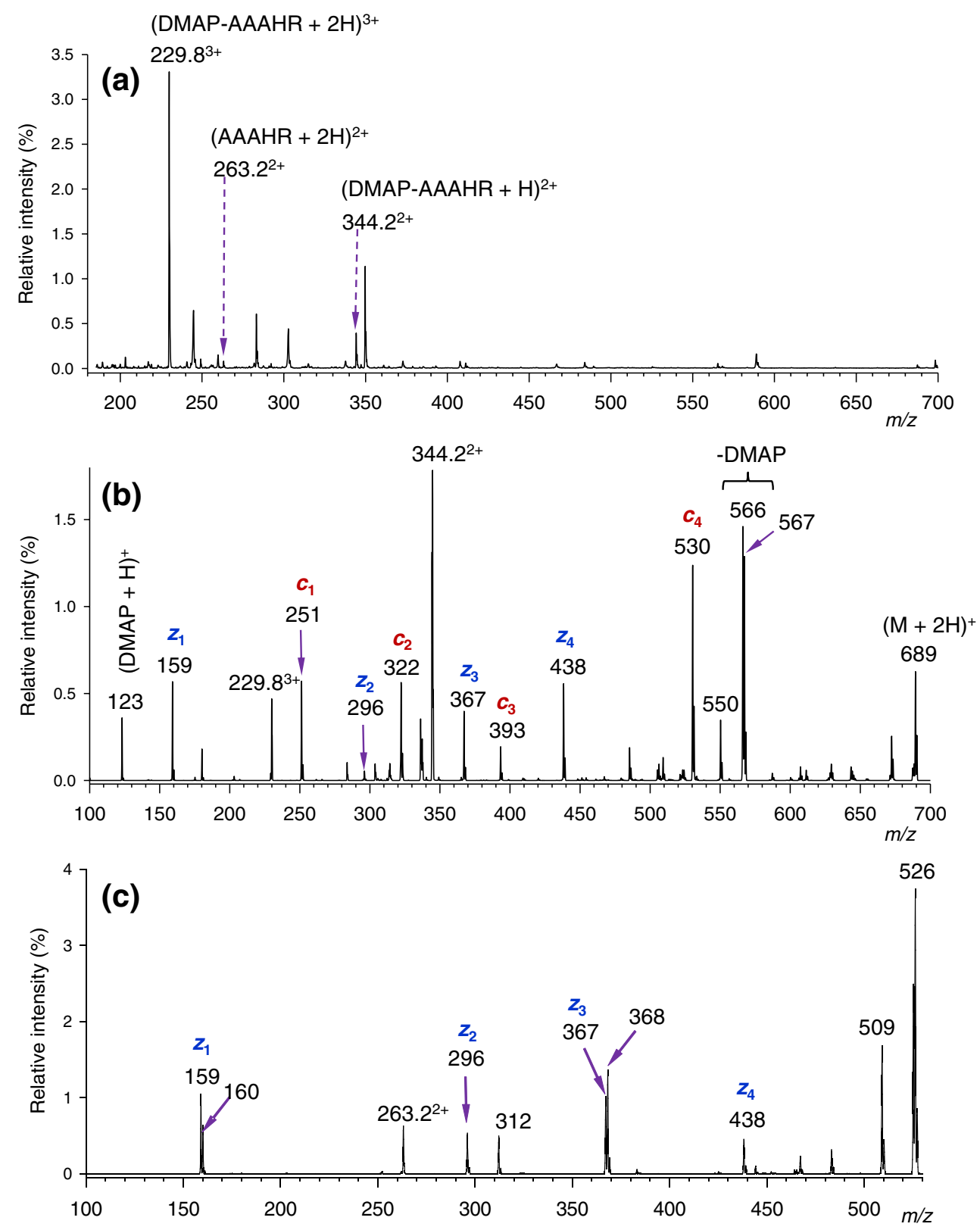

Figure 2. (a) Electrospray mass spectrum of a reaction mixture from tagging peptide AAAHR with DMAP. (b) ETD mass spectrum ( $500 \mathrm{~ms}$ reaction time) of the triply charged (DMAP-ac-AAAHR $+2 \mathrm{H})^{3+}$ ion at $\mathrm{m} / \mathrm{z} 229.8$. (c) ETD mass spectrum (200 ms reaction time) of a doubly charged $(A A A H R+2 H)^{2+}$ ion at $m / z$ 263.2. Relative intensities are given as percentages of the sum of the charge-reduced ion intensities

$\mathbf{2}^{\mathbf{2 +}}$ as local energy minima (Scheme 2). The global energy minimum for $\mathbf{1}^{\mathbf{2 +}}$ was structure $\mathbf{1 \mathbf { a } ^ { 2 + }}$ by combined B3LYP and MP2/6-311++G(2d,p) enthalpy calculations and also according to free energies (Table 2). The $\varepsilon$-ammonium group in $\mathbf{1 a}^{\mathbf{2 +}}$ has an $\mathrm{H}$-bond to the carboxyl carbonyl oxygen while maintaining effective spatial separation of the two charged groups to minimize Coulomb repulsion [15]. This can be gauged by the distance between the pyridine and Lys $\varepsilon$ ammonium $\mathrm{N}$ atoms, which is $12.6 \AA$ in $\mathbf{1 a}^{\mathbf{2 +}}$. The other lowenergy conformers have less favorable combinations of lysine $\mathrm{H}$-bonding and charge separation. For example, $\mathbf{1 b}^{\mathbf{2 +}}$ has the lysine $\varepsilon$-ammonium internally solvated by both the $\mathrm{COOH}$ and
Ala amide carbonyls, which leads to increased Coulomb repulsion and also decreases the ion entropy due to restricted rotations about backbone single bonds. Similar effects play a role in $\mathbf{1} \mathbf{c}^{\mathbf{2 +}}$. Conformer $\mathbf{1} \mathbf{d}^{\mathbf{2 +}}$ with an extended lysine side chain is disfavored by enthalpy because of a loss of lysine $\mathrm{H}$ bonding, but gains entropy by unimpeded backbone and sidechain rotations.

The most stable conformer of $\mathbf{2}^{\mathbf{2 +}}\left(\mathbf{2 a}^{\mathbf{2 +}}\right.$, Scheme 2$)$ had the lysine $\varepsilon$-ammonium internally solvated by the carboxyl carbonyl. A virtually isoenergetic conformer $\left(2 \mathbf{b}^{2+}\right)$ showed the lysine $\varepsilon$-ammonium $\mathrm{H}$-bonding to the $\mathrm{COOH}$ and amide cabonyls, but was entropically disfavored against $\mathbf{2 a}^{\mathbf{2}}$, 

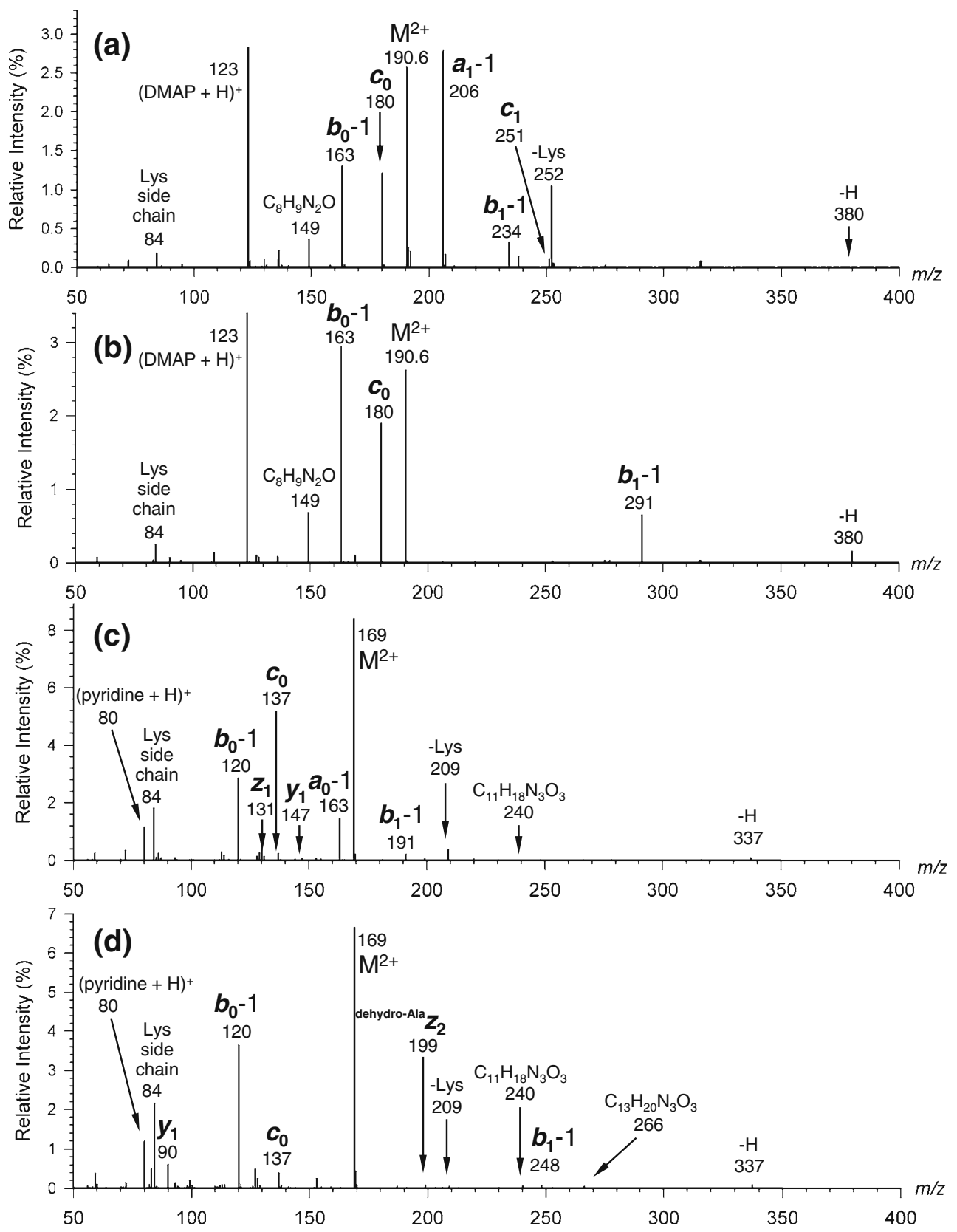

Figure 3. ECD mass spectra of doubly charged ions from (a) DMAP-ac-AK $\left(\mathbf{1}^{2+}\right)$, (b) DMAP-ac-KA $\left(\mathbf{2}^{2+}\right)$, (c) pyrid-ac-AK $\left(\mathbf{3}^{2+}\right)$, and (d) pyrid-ac-KA $\left(4^{2+}\right)$ collected on an LTQ FT-ICR instrument. Relative intensities are given as percentages of the sum of the charge-reduced ion intensities

which represented the global free energy minimum (Table 2). Another low-energy conformer $\left(\mathbf{2} \mathbf{c}^{2+}\right)$ had the lysine $\varepsilon^{-}$ ammonium internally solvated by the carboxyl group only and was isoenergetic by free energy with $\mathbf{2} \mathbf{b}^{\mathbf{2 +}}$. Structures $\mathbf{1} \mathbf{a}^{\mathbf{2 +}}$ and $\mathbf{2 \mathbf { a } ^ { 2 + }}$ were considered precursors for charge reduction and further radical-induced dissociations.

\section{Electron Transfer Energetics}

The energy balance $\Delta E$ for electron transfer between the anion-radical donor and the peptide ion acceptor is expressed by Equation (1) [50]:

$$
\Delta E=R E_{\mathrm{a}}(\text { ion })-\left[E A(\text { donor })+\Delta E_{\mathrm{exc}}(\text { donor })\right],
$$

where $R E_{\mathrm{a}}$ (ion) is the ion adiabatic recombination energy, $E A$ (donor) is the electron affinity of the neutral donor molecule, which is equal to the anion adiabatic electron binding energy, and $\Delta E_{\text {exc }}$ (donor) is the excitation energy for the electronic state of the neutral donor molecule. Positive $\Delta E$ means that the electron transfer is exoergic. For fluoranthene, in particular, $E A=0.63 \mathrm{eV}$ [51] and $\Delta E_{\text {exc }}($ donor $)=0,3.06,3.45,3.83$, and $4.32 \mathrm{eV}$ for the $\mathrm{S}_{0^{-}}$ 

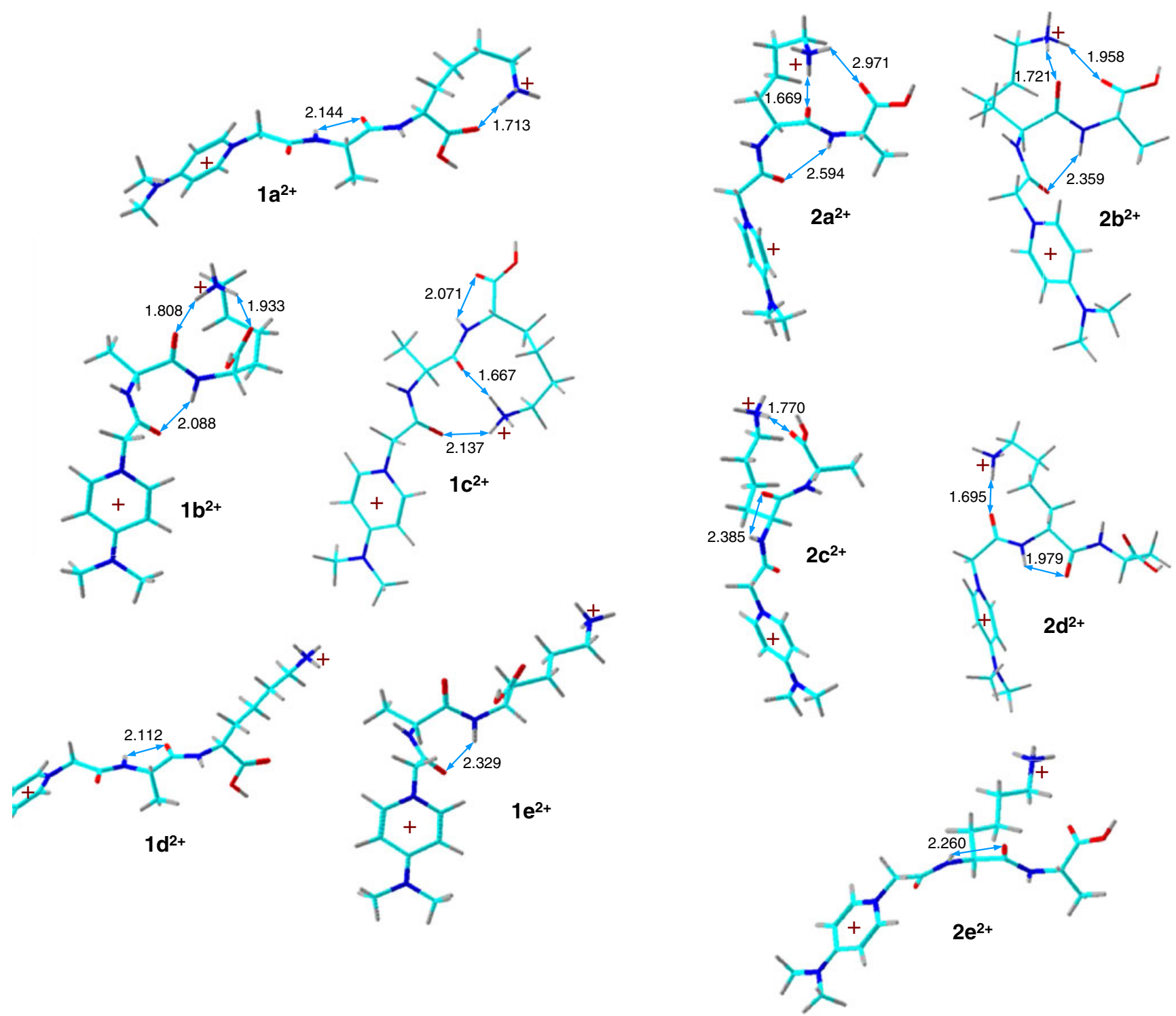

Scheme 2. B3LYP/6-31+G(d,p) optimized structures of the lowest-energy conformers $1 a^{2+}-1 e^{2+}$ and $2 a^{2+}-2 e^{2+}$

$\mathrm{S}_{4}$ singlet electronic states [52-54]. The calculated recombination energies of $\mathbf{1}^{\mathbf{2 +}}$ and $\mathbf{2}^{\mathbf{2 +}}$ conformers are collated in Table 3 and range from 5.83 to $6.5 \mathrm{eV}$. When used in Equation (1), the $R E$ indicate that electron transfer from [fluoranthene] ${ }^{--}$to the charge-tagged peptides is always exoergic. However, the excitation energy deposited in the charge-reduced peptide ion depends on the electronic state of the departing fluoranthene molecule and can range from 0.88 for the $\mathrm{S}_{4}$ state to $5.2 \mathrm{eV}$ for the $\mathrm{S}_{0}$ state. In contrast, the capture of a free electron results in the excitation of the charge-reduced ion, which is expressed by the adiabatic recombination energy of the precursor ion. The $R E_{\mathrm{a}}$ (ion) values in Table 3 indicate that a substantially greater excitation energy is imparted to the charge-reduced ions by ECD compared to ETD. These figures are important when discussing the dissociation energetics.

\section{Cation-Radical Structures of DMAP-ac- $\boldsymbol{A K} / \boldsymbol{K} \boldsymbol{A}$}

Electron attachment to $\mathbf{1 a}^{\mathbf{2 +}}$ was $5.83-6.07 \mathrm{eV}$ exoergic to produce the isomeric cation radicals $\mathbf{1 a}^{+\cdot}$ and $\mathbf{1 b}^{+\cdot}$ (Scheme 3). Of these two cation-radical conformers, the latter was $23 \mathrm{~kJ} \mathrm{~mol}^{-1}$ more stable than the former (Table 4). $\mathbf{1 b}^{+\bullet}$ has the same bond connectivity as $\mathbf{1 c}^{\mathbf{2 +}}$ but shows a shorter H-bond between the tag acetyl oxygen and a Lys ammonium hydrogen $(1.716 \AA)$. $\mathbf{1 a}^{+\bullet}$ has the same bond connectivity as $\mathbf{1 b}^{\mathbf{2 +}}$ but shows a shorter H-bond between the tag acetyl oxygen and the Lys amide hydrogen (1.809 $\AA)$. Both $\mathbf{1 a}^{+\bullet}$ and $\mathbf{1 b}^{+\bullet}$ show $>97 \%$ of the spin density spread about the entire 4-dimethylaminopyridine group. This moiety was also found via calculation to have a -0.18 negative charge in both of the mentioned species, whereas the positive charge is carried by the lysine $\varepsilon$-ammonium 
Table 2. Relative enthalpies and free energies of doubly charged DMAP-acetyl-dipeptides

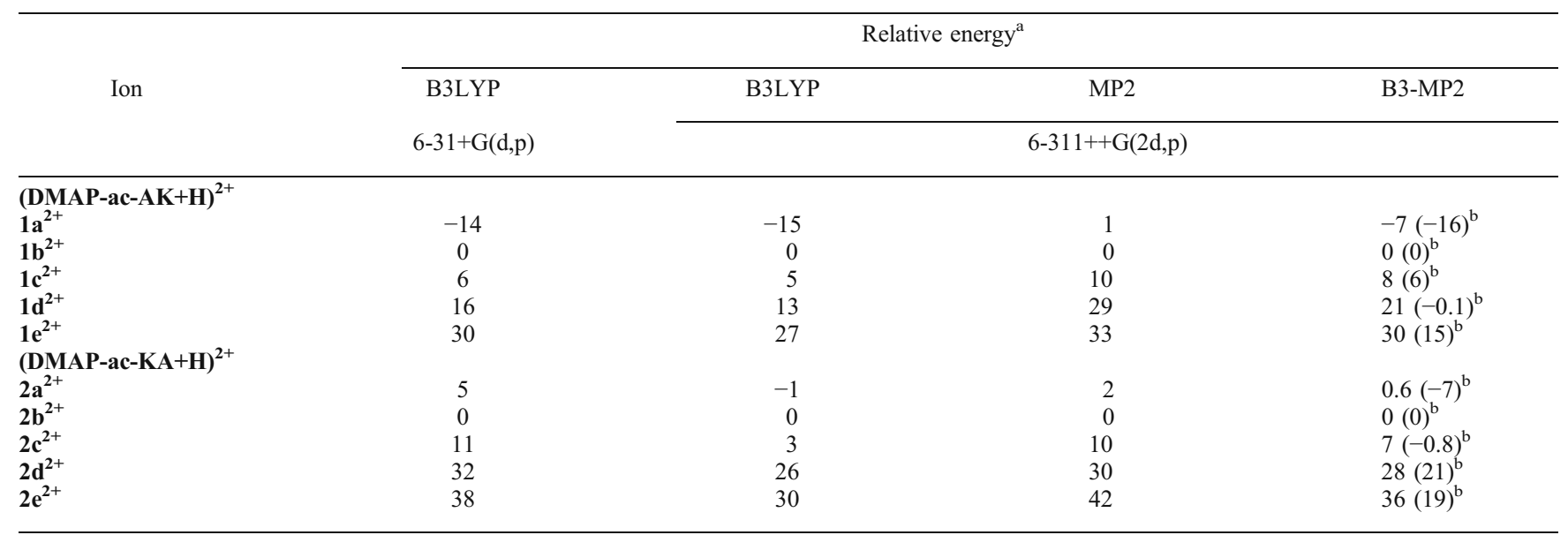

${ }^{\mathrm{a}}$ In units of $\mathrm{kJ} \mathrm{mol}^{-1}$, and including B3LYP/6-31+G(d,p) zero-point vibrational energies and $298 \mathrm{~K}$ enthalpies

${ }^{\mathrm{b}}$ Relative free energies at $298 \mathrm{~K}$

group. This electron distribution corresponds to the ground electronic state of $\mathbf{1}^{+\boldsymbol{\bullet}}$ and is consistent with the lower intrinsic recombination energy of the internally solvated lysine $\varepsilon$-ammonium group compared to that of 4-dimethylaminopyridinium [31, 32].

Charge reduction of $\mathbf{2}^{\mathbf{2}}$ ions brings about the formation of cation radicals, which can exist as several conformers differing in the lysine $\varepsilon$-ammonium hydrogen bonding. The general structural feature of these cation radicals $\left(2^{+\bullet}\right)$ is that they maintain the lysine $\varepsilon$-ammonium as the charge-carrying group, whereas the odd electron is delocalized over the 4dimethylaminopyridine moiety. Of the two most stable conformers, $\mathbf{2} \mathbf{a}^{+\bullet}$ has the same H-bonding pattern as $\mathbf{2} \mathbf{a}^{\mathbf{2 +}}$ but shows a shorter hydrogen bond between the tag acetyl oxygen and the lysine amide hydrogen at $1.974 \AA$. The removal of coulombic repulsion between the charge groups in $\mathbf{2} \mathbf{a}^{\mathbf{2}}$ upon electron attachment allows side-chain folding in the charge-reduced cation radical, leading to conformer $\mathbf{2} \mathbf{b}^{+\bullet}$, which is the global energy minimum (Table 4). $\mathbf{2 b}^{+\bullet}$ displays a unique internal solvation of the charged group in that it develops a hydrogen bond between the dimethylamine nitrogen and one of the $\varepsilon$-ammonium hydrogens at $1.903 \AA$ (Scheme 3).

\section{Dissociation Pathways of DMAP-ac-AK/KA Cation Radicals}

Electron transfer to DMAP-tagged dipeptide ions induced the loss of a hydrogen atom, $\mathrm{N}-\mathrm{C}_{\alpha}$ bond dissociations of both amide bonds, and another $\mathrm{N}-\mathrm{C}_{\alpha}$ bond dissociation affecting the pyridine-linker bond. The energetics of the latter have been previously analyzed for a DMAP-tagged GK dipeptide and shown to have a low threshold energy $\left(9 \mathrm{~kJ} \mathrm{~mol}^{-1}\right)$, and to require $67-70 \mathrm{~kJ} \mathrm{~mol}^{-1}$ in the pertinent transition state [31,32]. We will use these values as benchmarks to be compared with the new data on $\mathrm{N}-\mathrm{C}_{\alpha}$ bond dissociations of amide bonds in cation radicals $\mathbf{1}^{+\cdot}$ and $\mathbf{2}^{+\cdot}$.

Dissociation of the Ala-Lys $\mathrm{N}-\mathrm{C}_{\alpha}$ bond to produce the $\boldsymbol{c}_{\mathbf{1}}$ ion was considered to start from $\mathbf{1 a}^{+\bullet}$, which had a favorable conformation for $\mathrm{H}$ atom transfer from the Lys $\varepsilon$-ammonium to the pertinent amide carbonyl (Scheme 4). The H-atom transfer required $65 \mathrm{~kJ} \mathrm{~mol}^{-1}$ in TS1 and formed aminoketyl

Table 3. Ion recombination energies

\begin{tabular}{|c|c|c|c|c|}
\hline \multirow{2}{*}{ Ion } & \multicolumn{4}{|c|}{ Recombination energy ${ }^{\mathrm{a}, \mathrm{b}}$} \\
\hline & $6-31+G(d, p)$ & $6-311++G(2 d, p)$ & & $6-311++G(2 d, p)$ \\
\hline $1 \mathrm{a}^{2+} \rightarrow 1 \mathrm{a}^{+\bullet}$ & 5.87 & $5.88(5.17)^{c}$ & $5.78(4.32)^{c}$ & $5.83(4.74)^{c}$ \\
\hline $1 \mathrm{a}^{2+} \rightarrow 1 \mathrm{~b}^{+\cdot}$ & 6.12 & 6.14 & 6.00 & 6.07 \\
\hline $1 \mathrm{~b}^{2+} \rightarrow 1 \mathrm{a}^{+\cdot}$ & 6.02 & $6.04(5.45)^{\mathrm{c}}$ & $5.79(4.94)^{\mathrm{c}}$ & $5.92(5.20)^{\mathrm{c}}$ \\
\hline $2 \mathrm{a}^{2+} \rightarrow 2 \mathrm{~b}^{+\cdot}$ & 6.18 & 6.20 & 6.12 & 6.16 \\
\hline $2 \mathrm{~b}^{2+} \rightarrow 2 \mathrm{a}^{+\cdot}$ & 6.03 & $6.11(5.49)^{\mathrm{c}}$ & $5.80(4.96)^{\mathrm{c}}$ & $5.95(5.23)^{\mathrm{c}}$ \\
\hline $2 \mathrm{~b}^{2+} \rightarrow 2 \mathrm{~b}^{+\cdot}$ & 6.14 & 6.22 & 6.11 & 6.17 \\
\hline $2 d^{2+} \rightarrow 2 b^{+\cdot}$ & 6.47 & $6.48(5.79)^{\mathrm{c}}$ & $6.42(5.37)^{\mathrm{c}}$ & $6.45(5.58)^{\mathrm{c}}$ \\
\hline
\end{tabular}

${ }^{\mathrm{a}}$ In units of $\mathrm{eV}$

${ }^{\mathrm{b}}$ Adiabatic recombination energies include zero-point corrections

${ }^{\mathrm{c}}$ Vertical recombination energies without zero-point corrections 

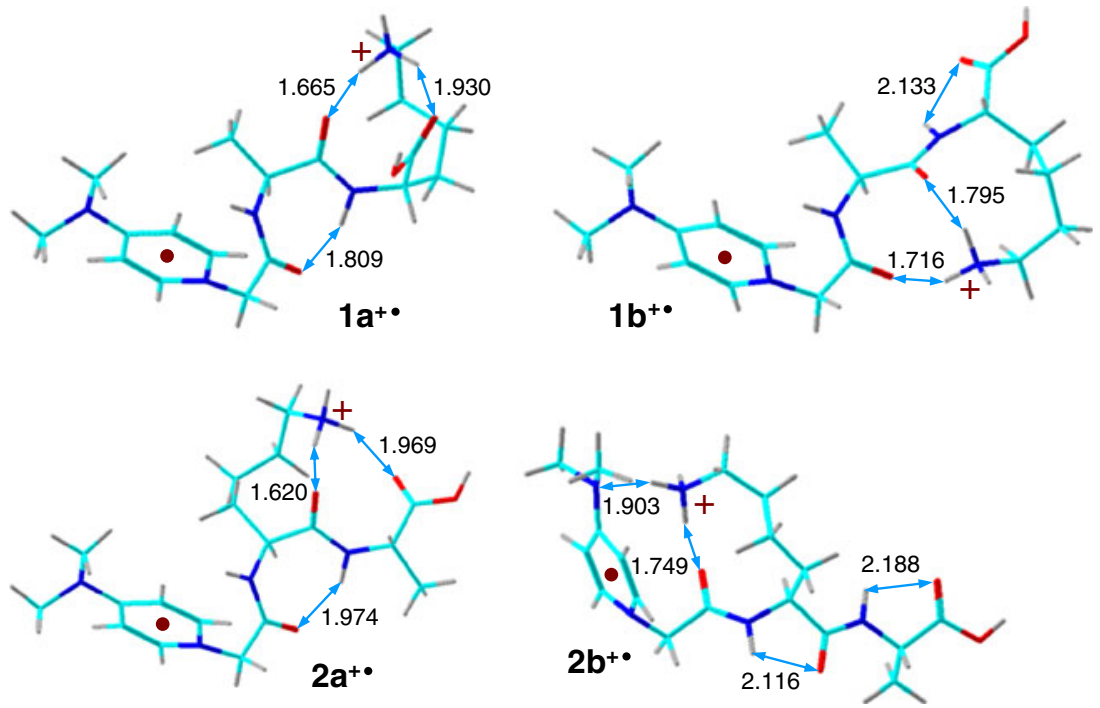

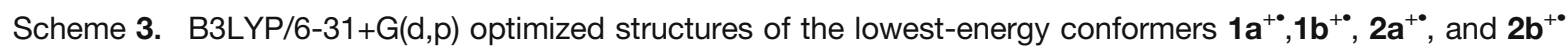

radical $1 \mathbf{c}^{+\bullet}$, which was $21 \mathrm{~kJ} \mathrm{~mol}^{-1}$ above $\mathbf{1 a}^{+\bullet}$ (Table 4). TS1 is a late transition state in which the $\mathrm{O}-\mathrm{H}$ bond has practically been formed at $1.072 \AA$ (Scheme 4). It should be noted that aminoketyl radical $\mathbf{1} \mathbf{c}^{+\bullet}$ can presumably exist in a variety of conformations, some of which may be more stable than structure $\mathbf{1 c}^{+\bullet}$. However, since an exhaustive conformational search of peptide cation radicals cannot be carried out, we proceeded with $\mathbf{1 c}^{+\bullet}$ as a plausible intermediate for further dissociations. $\mathrm{N}-\mathrm{C}_{\alpha}$ bond cleavage in $\mathbf{1} \mathbf{c}^{+\bullet}$ was found to proceed through TS2, which was $93 \mathrm{~kJ} \mathrm{~mol}^{-1}$ above the reactant and $114 \mathrm{~kJ} \mathrm{~mol}^{-1}$ above $\mathbf{1 a}^{+\bullet}$. The $\mathrm{N}-\mathrm{C}_{\alpha}$ bond dissociation formed a complex of the incipient $c_{\mathbf{1}}$ ion in its enolimine tautomeric form and the neutral $\boldsymbol{z}_{1}$ radical $\left(\mathbf{1 d}^{+\bullet}\right)$. Complex $\mathbf{1 d}^{+\bullet}$ was $33 \mathrm{~kJ} \mathrm{~mol}^{-1}$ below the starting chargereduced ion $\mathbf{1 a}^{+\cdot}$, indicating that the $\mathrm{N}-\mathrm{C}_{\alpha}$ bond dissociation was exothermic. However, $\boldsymbol{c}_{\mathbf{1}}$ and $\boldsymbol{z}_{\mathbf{1}}$ fragment separation in $\mathbf{1 d}^{+\bullet}$ was $69 \mathrm{~kJ} \mathrm{~mol}^{-1}$ endothermic, making the overall fragmentation $36 \mathrm{~kJ} \mathrm{~mol}^{-1}$ endothermic (Table 4). This example illustrates that the energies for $\mathrm{N}-\mathrm{C}_{\alpha}$ bond dissociations and the overall fragmentation upon ETD are very different and must be distinguished when discussing the ETD mechanisms. Furthermore, $\mathbf{1 d}^{+\bullet}$ can follow an energetically more favorable

Table 4. Relative energies of (DMAP-ac-AK $+\mathrm{H}$ ) cation radicals

\begin{tabular}{|c|c|c|c|c|}
\hline \multirow{3}{*}{ Reaction } & \multicolumn{4}{|c|}{ Relative energy ${ }^{\mathrm{a}, \mathrm{b}}$} \\
\hline & B3LYP & B3LYP & MP2 & B3-MP2 \\
\hline & $6-31+G(d, p)$ & $6-311++G(2 d, p)$ & & $6-311++\mathrm{G}(2 \mathrm{~d}, \mathrm{p})$ \\
\hline $\mathbf{1 a}^{+\bullet} \rightarrow 1 b^{+\bullet}$ & -24 & -25 & -21 & -23 \\
\hline $1 \mathrm{a}^{+\bullet} \rightarrow \mathrm{TS} 1$ & 42 & 44 & 86 & 65 \\
\hline $1 \mathrm{a}^{+\bullet} \rightarrow 1 \mathrm{c}^{+\bullet}$ & 26 & 28 & 15 & 21 \\
\hline $1 \mathrm{c}^{+\bullet} \rightarrow \mathrm{TS} 2$ & 87 & 84 & 101 & 93 \\
\hline $1 \mathrm{c}^{+\cdot} \rightarrow 1 \mathrm{~d}^{+\bullet}$ & -70 & -75 & -34 & -55 \\
\hline $1 \mathrm{c}^{+\cdot} \rightarrow 1 \mathrm{e}^{+\cdot}$ & -132 & -136 & -94 & -115 \\
\hline $1 \mathrm{~d}^{+\bullet} \rightarrow 1 \mathrm{e}^{+\bullet}$ & -62 & -61 & -60 & -61 \\
\hline $1 \mathrm{a}^{+\cdot} \rightarrow \mathbf{1 d}^{+\bullet}$ & -45 & -47 & -19 & -33 \\
\hline $1 \mathrm{a}^{+\bullet} \rightarrow 1 \mathrm{e}^{+\bullet}$ & -107 & -108 & -79 & -94 \\
\hline $\mathbf{1 a}^{+\bullet} \rightarrow{ }^{\text {enolimine-AK }} c_{1}^{+}+{ }^{A K} z_{1} \cdot$ & 16 & 6 & 66 & 36 \\
\hline $\mathbf{1 a}^{+\bullet} \rightarrow{ }^{\text {amide-AK}} c_{1}^{+}+{ }^{\mathrm{AK}_{z_{1}}} \cdot{ }^{\bullet 1}$ & -56 & -64 & 1 & -31 \\
\hline $1 \mathrm{~b}^{+\cdot} \rightarrow \mathrm{TS3}$ & -4 & 0 & 3 & 2 \\
\hline $1 \mathrm{~b}^{+\bullet} \rightarrow 1 \mathrm{f}^{+\cdot}$ & 0 & 3 & 1 & 2 \\
\hline $\mathbf{1 f}^{+\bullet} \rightarrow \mathrm{TS} 4$ & 61 & 60 & 74 & 67 \\
\hline $1 \mathrm{f}^{+\bullet} \rightarrow 1 \mathrm{~g}^{+\bullet}$ & -32 & -36 & -18 & -27 \\
\hline $1 \mathrm{f}^{+\bullet} \rightarrow 1 \mathrm{~h}^{+\cdot}$ & -110 & -113 & -89 & -101 \\
\hline $1 \mathrm{~b}^{+\bullet} \rightarrow \mathbf{1 \mathrm { g } ^ { + \bullet }}$ & -32 & -33 & -17 & -25 \\
\hline $1 \mathrm{~b}^{+\cdot} \rightarrow 1 \mathrm{~h}^{+\cdot}$ & -110 & -109 & -88 & -99 \\
\hline $\mathbf{1 b}^{+\bullet} \rightarrow{ }^{\text {enolimine-AK}}{c_{0}}^{+}+{ }^{A K_{z_{2}}}{ }^{\bullet}$ & 47 & 43 & 83 & 63 \\
\hline $\mathbf{1 b}^{+\cdot} \rightarrow{ }^{\text {amide-AK}} \boldsymbol{c}_{0}^{+}+{ }^{\mathrm{AK}_{z_{2}}}{ }^{\cdot{ }^{* 2}}$ & -23 & -27 & 17 & -5 \\
\hline
\end{tabular}

${ }^{\mathrm{a} I n}$ units of $\mathrm{kJ} \mathrm{mol}^{-1}$

${ }^{\mathrm{b}}$ Including B3LYP/6-31+G(d,p) zero-point energies and referring to $0 \mathrm{~K}$ 

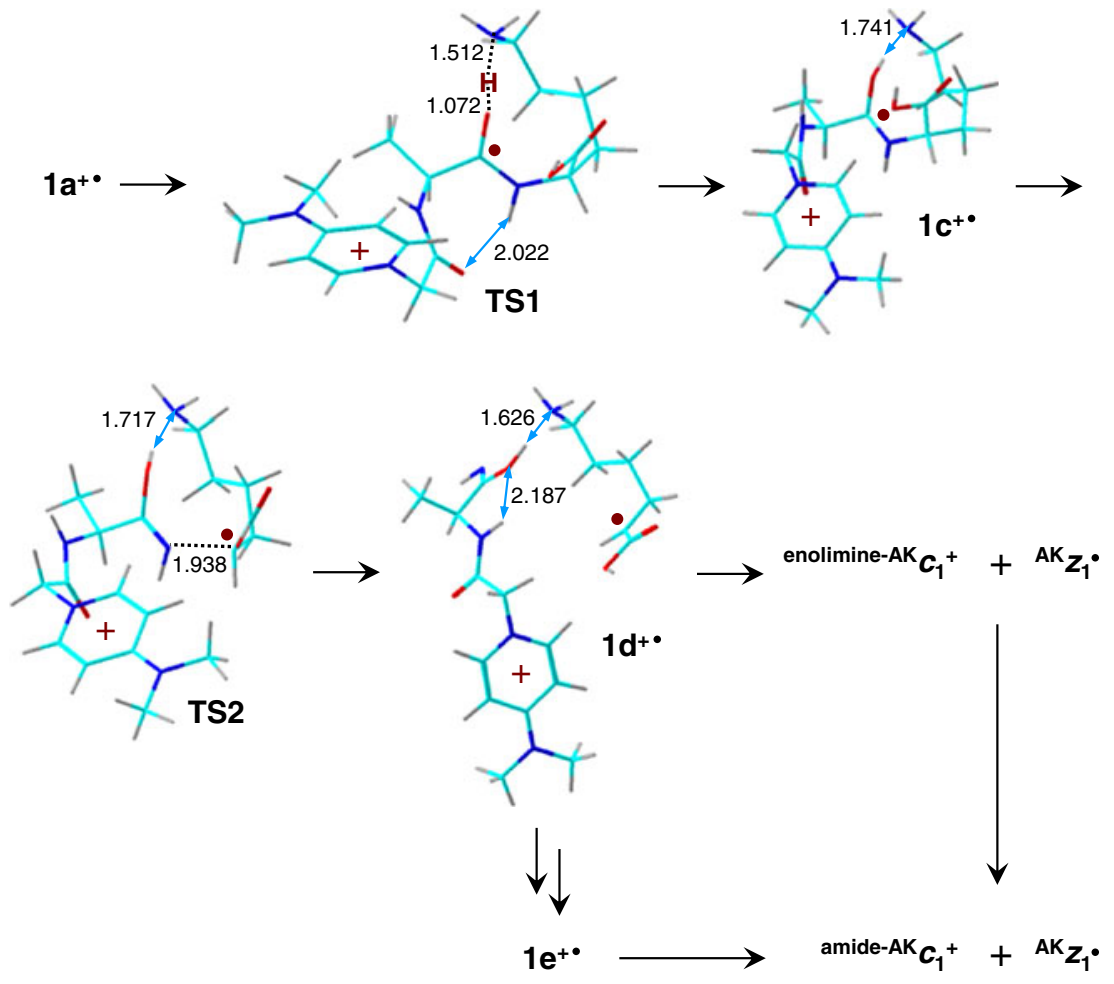

Scheme 4. Backbone dissociations of $\mathbf{1 a ^ { + \bullet }}$
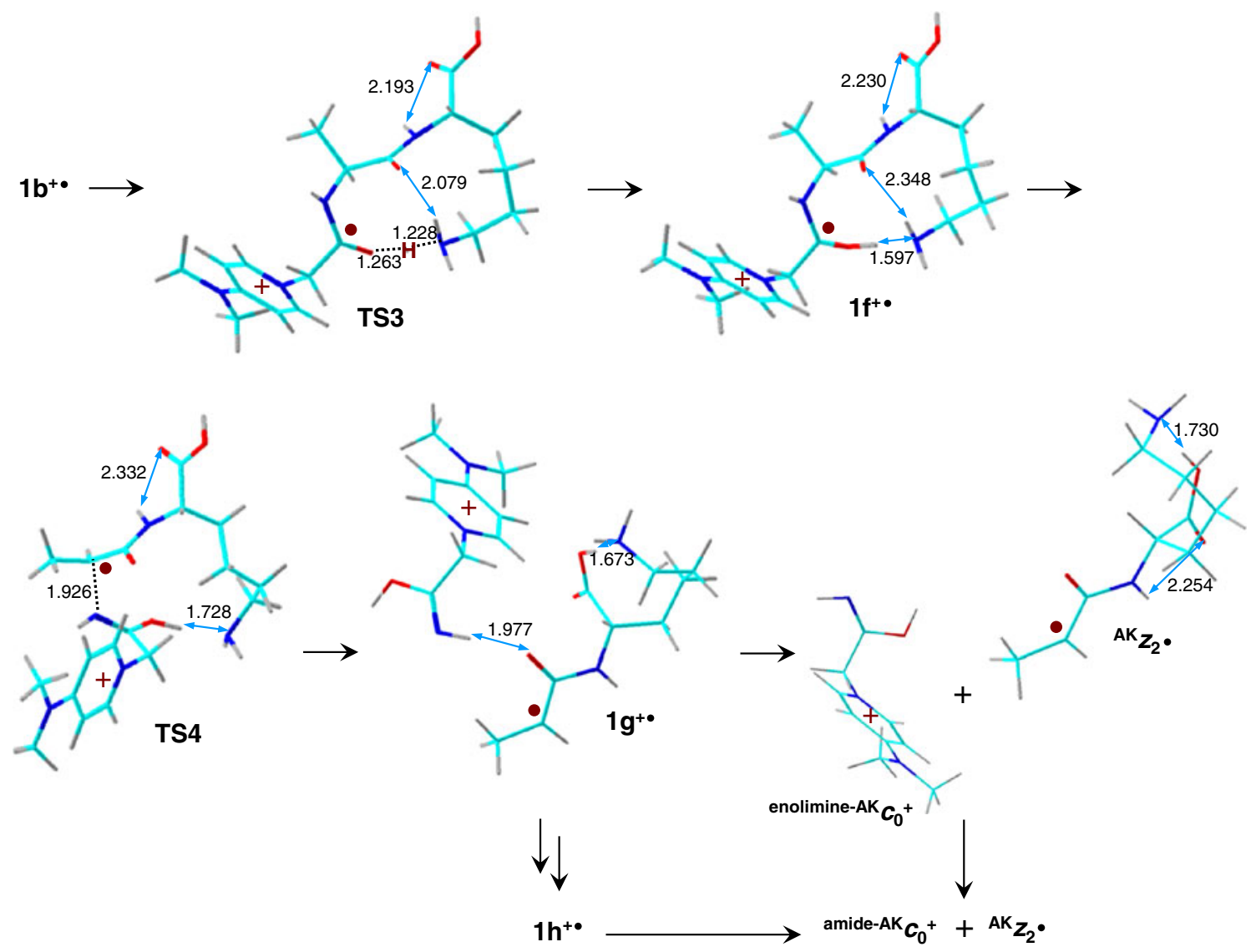

Scheme 5. Backbone dissociations of $\mathbf{1 b}^{+\bullet}$ 
pathway by isomerizing to another complex $1 \mathbf{e}^{+\bullet}\left(-61 \mathrm{~kJ} \mathrm{~mol}^{-1}\right.$ relative to $\mathbf{1 d}^{+\bullet}$, Table 4), in which the $\boldsymbol{c}_{\mathbf{1}}$ ion moiety is in the more stable amide tautomeric form (Scheme S1 of the ESM). Fragment separation in $\mathbf{1} \mathbf{e}^{+\bullet}$ is also endothermic, but occurs at $-31 \mathrm{~kJ} \mathrm{~mol}^{-1}$ relative to $\mathbf{1 a}^{+\bullet}$, making this dissociation pathway exothermic.

Overall, the reactions leading to the formation of $c_{1}$ had to cross TS2 as the highest point on the PES at $114 \mathrm{~kJ} \mathrm{~mol}^{-1}$. This is higher than the presumed energy barrier for the loss of DMAP, which was calculated to be at $67-70 \mathrm{~kJ} \mathrm{~mol}^{-1}$ in related peptide radicals [31, 32]. The fact that these two dissociations are kinetically competitive indicates that the calculated PES would have to be modified to accurately describe the actual dissociations. Modifications to this end may involve finding lower energy conformers for TS2 or $\mathbf{1} \mathbf{c}^{+\bullet}$ or a higher energy TS for the DMAP loss, which both would kinetically favor Ala-Lys $\mathrm{N}-\mathrm{C}_{\alpha}$ bond dissociation.

Dissociation of the tag-Ala $\mathrm{N}-\mathrm{C}_{\alpha}$ bond to produce the $\boldsymbol{c}_{\mathbf{0}}$ ion was considered to start from conformer $\mathbf{1 b}^{+\bullet}$, which had an appropriate arrangement of the Lys $\varepsilon$-ammonium and the tag amide carbonyl (Scheme 5). $\mathrm{H}$-atom migration in $\mathbf{1 b}^{+\cdot}$ required an extremely low activation energy in TS3 and produced aminoketyl radical $\mathbf{1 f}^{{ }^{\bullet}}$, which was practically isoenergetic with $\mathbf{1 b}^{+\cdot} . \mathrm{N}-\mathrm{C}_{\alpha}$ bond cleavage in $\mathbf{1 f}^{+}$ proceeded through TS4 $\left(67 \mathrm{~kJ} \mathrm{~mol}^{-1}\right.$ relative to $\mathbf{1 f}^{+^{\bullet}}$,
Table 4), forming a complex of the enolimine tautomeric form of the $\boldsymbol{c}_{\mathbf{0}}$ ion and the complementary $\boldsymbol{z}_{\mathbf{2}}$ radical $\left(\mathbf{1} \mathrm{g}^{+\bullet}\right)$, which was $25 \mathrm{~kJ} \mathrm{~mol}^{-1}$ more stable than $\mathbf{1 b}^{+\bullet}$. A further dissociation of $\mathbf{~}^{+\bullet}$ can follow an endothermic pathway to separate the incipient fragments at $63 \mathrm{~kJ} \mathrm{~mol}^{-1}$ relative to $\mathbf{1 b}^{+\bullet}$. An energetically more favorable pathway involves enolimine-amide isomerization in $\mathbf{1 g}^{+\bullet}$, forming more stable complexes (e.g., $\mathbf{~ h}^{+\bullet}$, Scheme S2 of the ESM), which can dissociate to produce an amide tautomer of the $c_{\mathbf{0}}$ ion at $-5 \mathrm{~kJ} \mathrm{~mol}^{-1}$ relative to $\mathbf{1 b}^{+\bullet}$.

A salient feature of the dissociation pathways discussed above is the energetics of the first step, which is the Lys $\varepsilon$ ammonium $\mathrm{H}$-atom migration. Analogous migrations have been studied for peptide radicals and cation radicals and shown to be substantially exothermic, requiring very low activation energies $[55,56]$. In contrast, the isomerizations in the chargetagged peptide cation radicals shown in Schemes 4 and 5 were uniformly endothermic and required substantial TS energies. The unusual properties of $\mathbf{1 \mathbf { a } ^ { + \bullet }}$ and $\mathbf{1 \mathbf { b } ^ { + \bullet }}$ can be understood by analyzing the electron distribution and excited electronic states that develop during the course of these reactions.

The ground electronic state of $\mathbf{1 a}^{+\cdot}(\boldsymbol{X})$ has the oddelectron density localized in the DMAP moiety, as represented by the corresponding $\pi$ orbital (SOMO, Figure 4). This electronic configuration does not allow for a migration of the Lys $\varepsilon$-ammonium hydrogen atom, which requires odd-

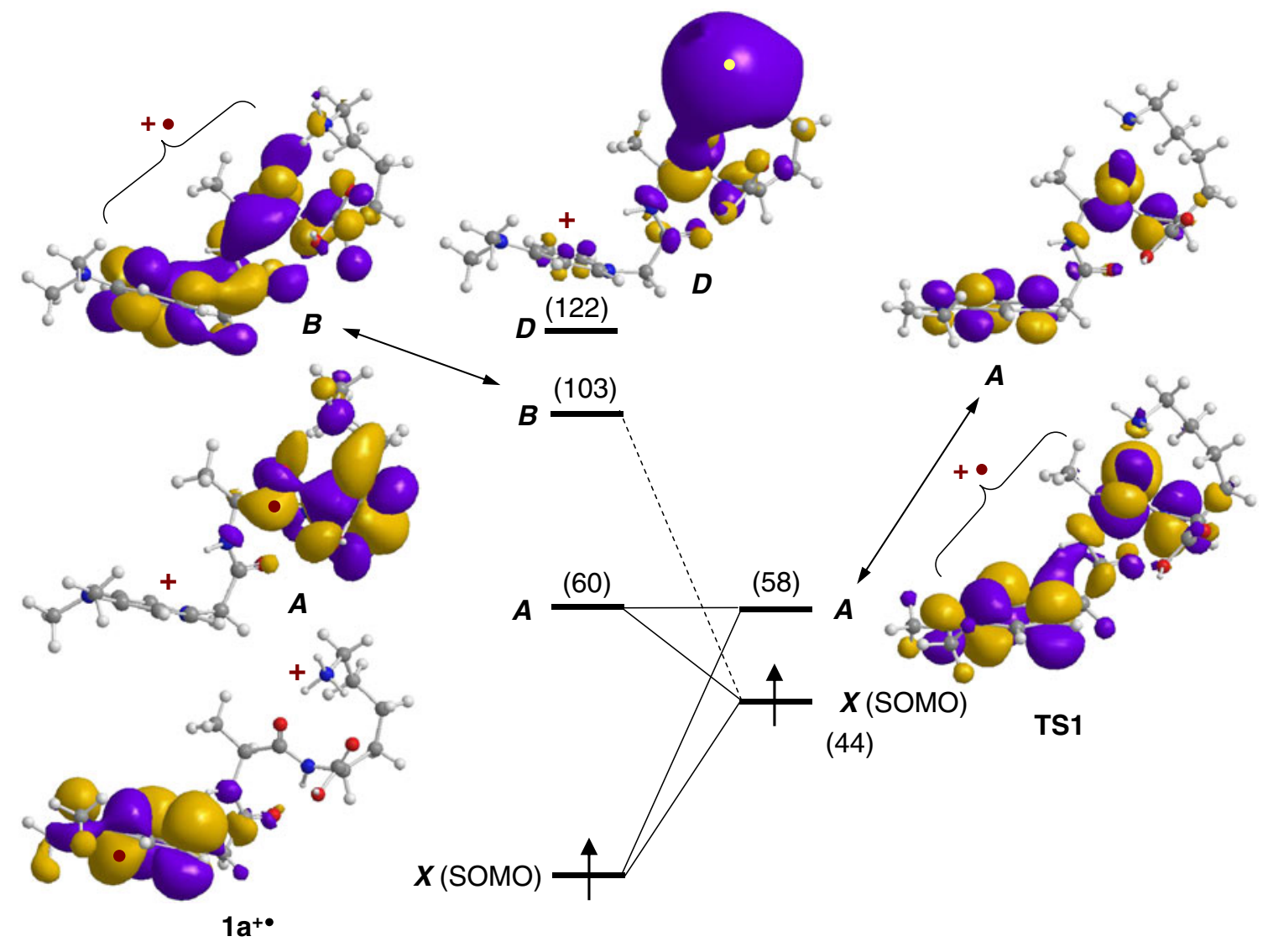

Figure 4. Electronic states for $\mathbf{1 a}^{+\bullet}$ and TS1 from TD-DFT calculations with B3LYP/6-311++G(2d,p). The orbital phases are distinguished by gold and purple colors. Energies are in $\mathrm{kJ} \mathrm{mol}^{-1}$ for vertical excitations 


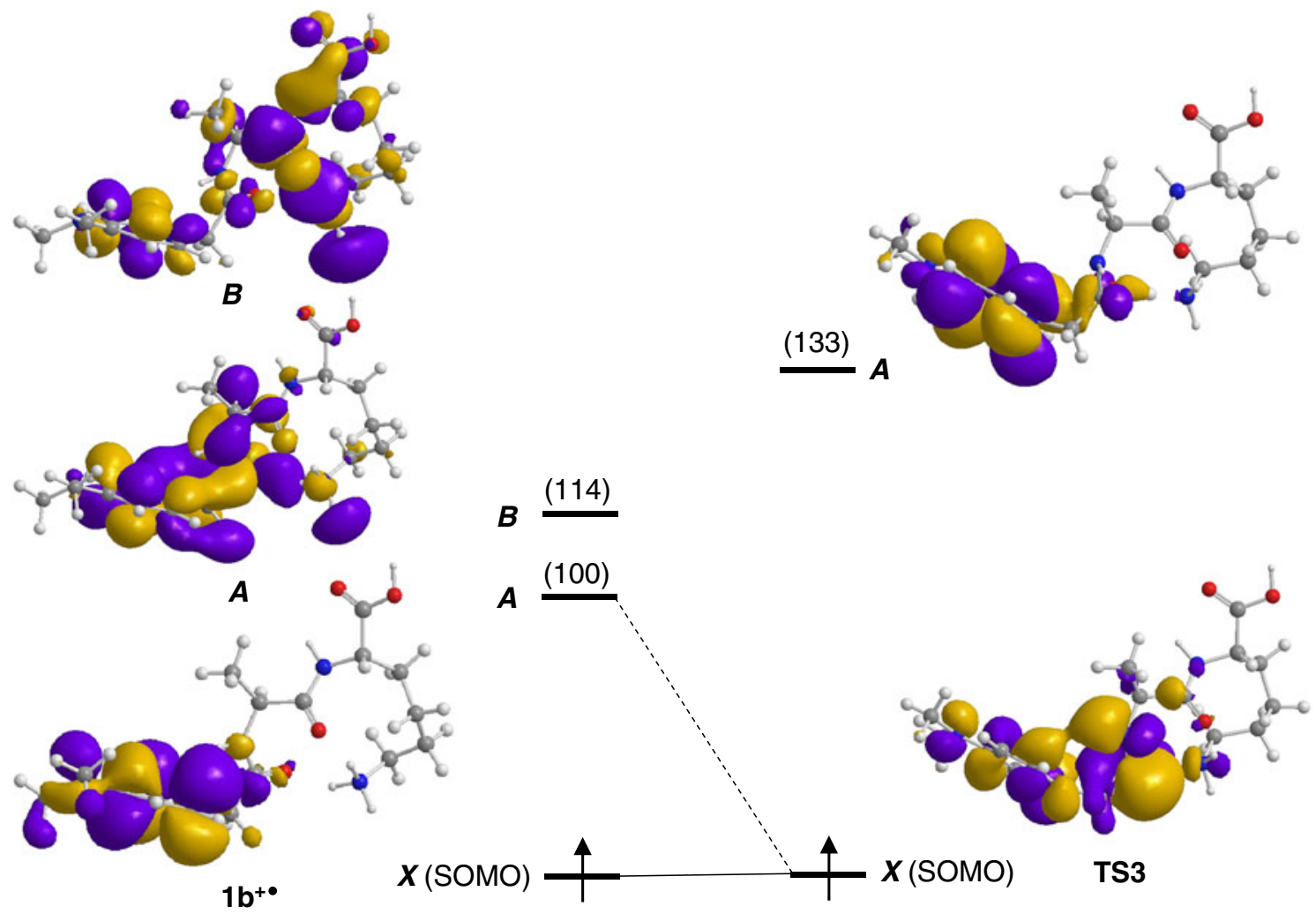

Figure 5. Electronic states for $\mathbf{1}^{\mathbf{b}^{\bullet}}$ and TS3 from TD-DFT calculations with B3LYP/6-311++G(2d,p). The orbital phases are distinguished by gold and purple colors. Energies are in $\mathrm{kJ} \mathrm{mol}^{-1}$ for vertical excitations
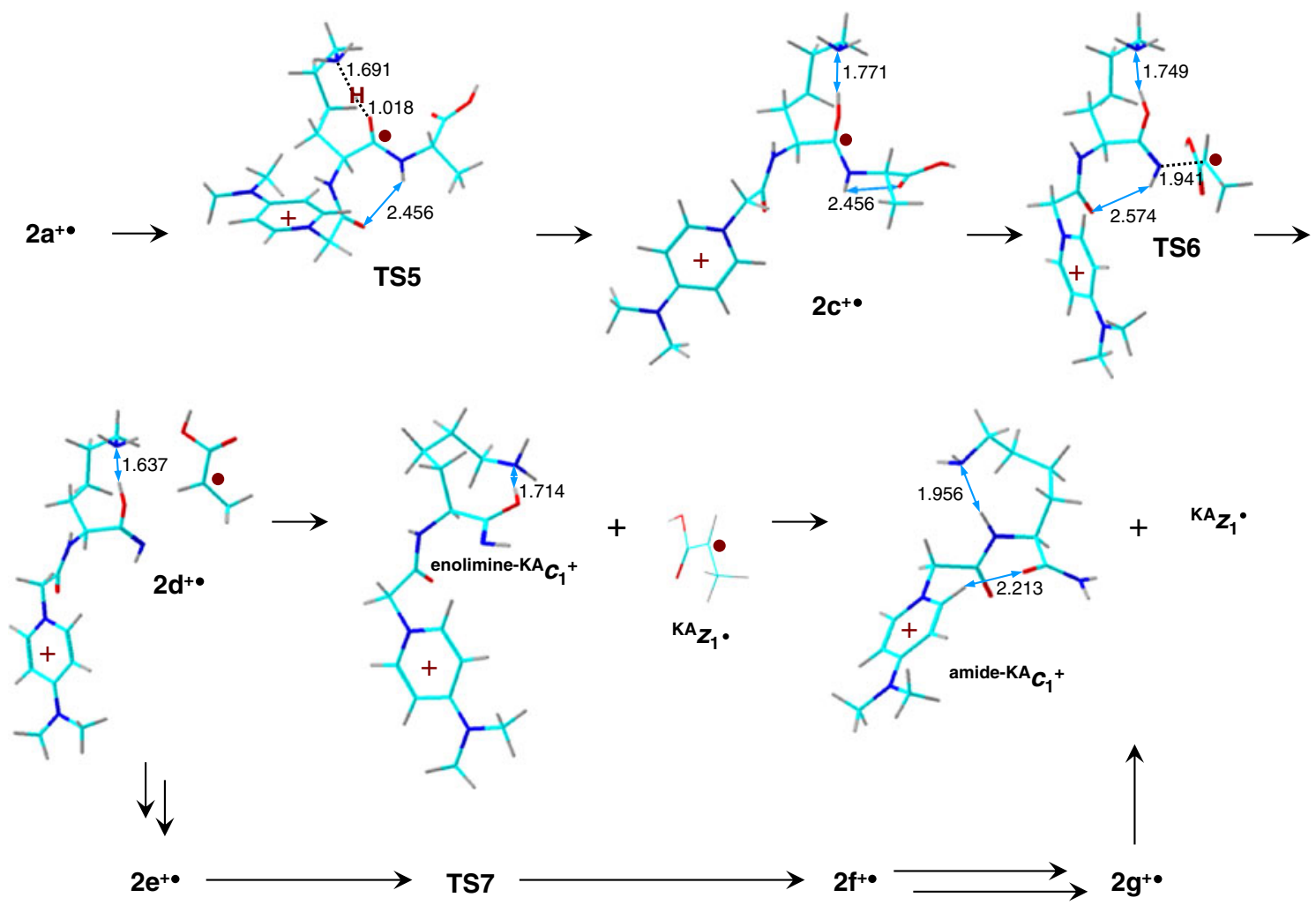

Scheme 6. Backbone dissociations of $\mathbf{2 a ^ { + \bullet }}$ 
T.W. Chung, et al.: Tunable Fixed-Charged Tags for Electron Transfer Dissociation of Peptides

Table 5. Relative energies of (DMAP-ac-KA $+\mathrm{H}$ ) cation radicals

\begin{tabular}{|c|c|c|c|c|}
\hline Reaction & \multicolumn{4}{|c|}{ Relative energy a,b } \\
\hline $2 \mathrm{a}^{+\bullet} \rightarrow \mathbf{2} \mathrm{b}^{+\bullet}$ & -10 & -11 & -30 & -21 \\
\hline $2 \mathrm{a}^{+\bullet} \rightarrow \mathrm{TS} 5$ & 41 & 42 & 57 & 49 \\
\hline $2 \mathrm{a}^{+\bullet} \rightarrow 2 \mathrm{c}^{+\bullet}$ & 22 & 22 & 29 & 26 \\
\hline $2 \mathrm{a}^{+\bullet} \rightarrow 2 \mathrm{~d}^{+\bullet}$ & 8 & 4 & 26 & 15 \\
\hline $2 \mathrm{a}^{+\bullet} \rightarrow 2 \mathrm{e}^{+\bullet}$ & -6 & -11 & 20 & 5 \\
\hline $2 \mathrm{e}^{+\bullet} \rightarrow \mathrm{TS} 7$ & 115 & 114 & 131 & 123 \\
\hline $2 \mathrm{e}^{+\bullet} \rightarrow 2 \mathrm{f}^{+\bullet}$ & -74 & -73 & -66 & -70 \\
\hline $2 \mathrm{a}^{+\bullet} \rightarrow \mathbf{2 \mathrm { f } ^ { \bullet }}$ & -80 & -84 & -46 & -65 \\
\hline $2 \mathrm{a}^{+\bullet} \rightarrow \mathbf{2 \mathrm { g } ^ { + \bullet }}$ & -96 & -97 & -8 & -88 \\
\hline $2 \mathrm{a}^{+\bullet} \rightarrow \rightarrow^{\text {enolimine-KA }} c_{1}^{+}+{ }^{\mathrm{KA}_{z_{2}}}$ & 7 & 2 & 39 & 21 \\
\hline $2 \mathrm{~g}^{+\bullet} \rightarrow 2 \mathrm{j}^{+\bullet}$ & -71 & -77 & -54 & -65 \\
\hline $2 \mathbf{b}^{+\bullet} \rightarrow \mathbf{2} \mathbf{i}^{+\bullet}$ & -31 & -33 & 5 & -14 \\
\hline $2 \mathrm{~b}^{+\bullet} \rightarrow 2 \mathrm{j}^{+\bullet}$ & -68 & -72 & -23 & -47 \\
\hline $2 \mathrm{a}^{+\bullet} \rightarrow^{\text {enolimine-KA }} c_{1}^{+}+{ }^{\mathrm{KA}} z_{2}{ }^{\bullet}$ & 66 & 56 & 135 & 95 \\
\hline $2 \mathrm{~b}^{+\bullet} \rightarrow \rightarrow^{\text {amide-KA}} c_{0}^{+}+{ }^{+} \mathrm{KA}_{z_{2}}{ }^{-}$ & -5 & -13 & 69 & 28 \\
\hline
\end{tabular}

${ }^{\mathrm{a}}$ In units of $\mathrm{kJ} \mathrm{mol}^{-1}$

${ }^{\mathrm{b}}$ Including B3LYP/6-31+G(d,p) zero-point energies and referring to $0 \mathrm{~K}$
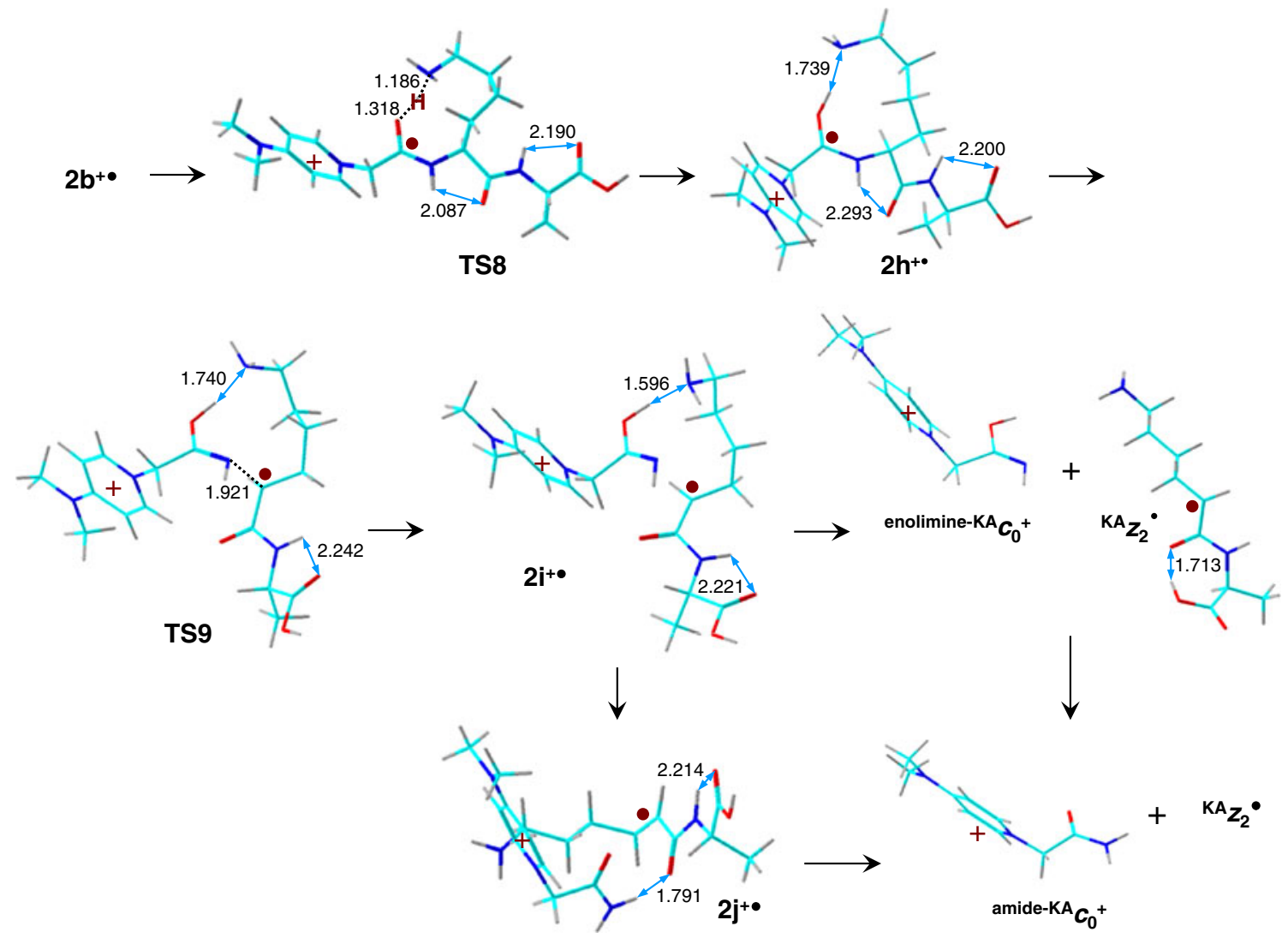

Scheme 7. Backbone dissociations of $\mathbf{2 b}^{+\bullet}$ 
electron density for a transfer to the recipient amide group $[15,55]$. Note that such migrations typically display the characteristics of proton-coupled electron transfer (PCET) [57-59], and therefore should be referred to as such. PCET is possible in the $\boldsymbol{A}, \boldsymbol{B}$, and presumably also higher excited states of $\mathbf{1 a}^{+\bullet}$ that have high odd-electron density in the Ala amide carbonyl, as represented by the pertinent orbitals for the $\boldsymbol{A}$ - $\boldsymbol{D}$ states (Figure 4). The activation energy associated with the PCET in $\mathbf{1 a}^{+\bullet}\left(E_{\mathrm{TS} 1}=65 \mathrm{~kJ} \mathrm{~mol}^{-1}\right.$ by B3-PMP2, 44 $\mathrm{kJ} \mathrm{mol}^{-1}$ by B3LYP) results from the mixing of the ground and excited states in TS1, with upper bounds given by the excitation energies in $\mathbf{1 a}^{+\bullet}$, for example $\Delta E_{\text {exc }}=60$ and 103 $\mathrm{kJ} \mathrm{mol}^{-1}$ for the $\boldsymbol{A}$ and $\boldsymbol{B}$ states, respectively (Figure 4). The loss of an $\mathrm{H}$ atom from $\mathbf{1 a}^{+\cdot}$ can occur from the $\boldsymbol{D}$ state $\left(\Delta E_{\mathrm{exc}}=122 \mathrm{~kJ} \mathrm{~mol}^{-1}\right)$, which has a character of a symmetryadjusted ammonium $3 s$ Rydberg (Figure 4). Rydberg $3 s$ states in ammonium radicals are known to undergo facile H-atom loss [60-62]. However, one cannot a priori exclude an alternative pathway for the $\mathrm{H}$ loss to occur from aminoketyl radical $1 \mathbf{c}^{+\bullet}$ in competition with the $\mathrm{N}-\mathrm{C}_{\alpha}$ bond cleavage through TS2. Although we did not study this reaction in detail here, previous studies of aminoketyl radicals indicated TS energies for H-atom loss ranging from $68[55]$ to $91 \mathrm{~kJ} \mathrm{~mol}^{-1}$ [63], which could be competitive with $\mathrm{N}-\mathrm{C}_{\alpha}$ bond cleavage through TS2 $\left(E_{\mathrm{TS} 2}=93 \mathrm{~kJ} \mathrm{~mol}^{-1}\right.$, Table 4$)$.

In contrast to $\mathbf{1 a}^{+\cdot}$, PCET involving the Lys $\varepsilon$-ammonium hydrogen migration to the tag-Ala amide group in $\mathbf{1 b}^{+\cdot}$ requires a low activation energy in TS3. This can be explained by the electron distribution in the ground electronic states, which show correlation between the oddelectron density in the corresponding SOMOs (Figure 5). Thus, the SOMO in $\mathbf{1 b}^{+\bullet}$, albeit mostly confined to the DMAP moiety, shows delocalization of electron density to the tag-Ala amide. Therefore, reaching the SOMO in TS3 requires only minor mixing of the reactant $\boldsymbol{X}$ and $\boldsymbol{A}$ states, resulting in a low activation energy.

Backbone dissociations in $\mathbf{2 a}^{+\bullet}$ can be discussed along the same lines as done for $\mathbf{1 a}^{+\bullet}$ and $\mathbf{1 b}^{+\bullet}$. The dissociation leading to the $c_{1}$ ion can be visualized as starting with a migration of a Lys $\varepsilon$-ammonium hydrogen to the Lys-Ala amide group, which requires $49 \mathrm{~kJ} \mathrm{~mol}^{-1}$ in TS5 (Scheme 6, Table 5), and forms an aminoketyl intermediate $\left(\mathbf{2} \mathbf{c}^{+*}\right)$. Note that $\mathbf{2} \mathbf{c}^{+\bullet}$ is $26 \mathrm{~kJ} \mathrm{~mol}^{-1}$ less stable than $\mathbf{2 \mathbf { a } ^ { + \bullet }}$. N-C $\mathrm{C}_{\alpha}$ bond cleavage may proceed through TS6, which is $71 \mathrm{~kJ} \mathrm{~mol}^{-1}$

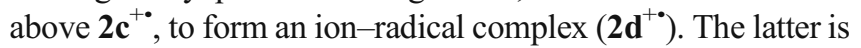
only weakly bound toward dissociation to the $c_{1}$ ion and $z_{1}$ radical (Scheme 6). However, complex $2 \mathbf{d}^{+\bullet}$ can undergo exothermic isomerizations by enolimine rotations and ionradical reorientation $\left(\mathbf{2 e}^{+\bullet}\right)$, or prototropic isomerization of the enol imine moiety to a more stable amide $[64,65]$ (Scheme S3 of the ESM). Interestingly, the latter isomerization is only weakly catalyzed by the incipient $z_{1}$ radical that helps to chaperon the enol $\mathrm{OH}$ proton to the imine nitrogen through TS7 at $123 \mathrm{~kJ} \mathrm{~mol}^{-1}$ above $\mathbf{2 \mathrm { e } ^ { + \bullet }}$ (Table 5). As expected, the enolimine-amide isomerization is substantially exothermic, forming complex $\mathbf{2 \mathbf { f } ^ { + }}$ or its reorientation isomers.
Dissociation of the tag-Lys $\mathrm{N}-\mathrm{C}_{\alpha}$ bond to produce the $\boldsymbol{c}_{\mathbf{0}}$ ion was considered to start from conformer $\mathbf{2} \mathbf{b}^{+\bullet}$ (Scheme 7). PCET migration of a Lys $\varepsilon$-ammonium hydrogen to the tagLys amide group requires a high activation energy (TS8) to

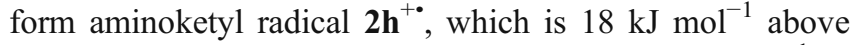
$\mathbf{2 b}^{+\bullet}$. N-C $\mathrm{C}_{\alpha}$ bond cleavage in $\mathbf{2 g}^{+\bullet}$ requires $45 \mathrm{~kJ} \mathrm{~mol}^{-1}$ in TS9 to give complex $\mathbf{2 \mathbf { i } ^ { + \bullet }}$ at $32 \mathrm{~kJ} \mathrm{~mol}^{-1}$ below $\mathbf{2 g}^{+\bullet}$. Fragment separation in $\mathbf{2 i}^{+\bullet}$ is $109 \mathrm{~kJ} \mathrm{~mol}^{-1}$ endothermic, but can be avoided by exothermic ion-radical pair reorientation and prototropic enolimine-amide isomerization $\left(\mathbf{2 j}^{+\bullet}\right)$. Dissociation of the latter complex is $75 \mathrm{~kJ} \mathrm{~mol}^{-1}$ endothermic, which brings the energy threshold for the separated $c_{1}$ and $z_{1}$ fragment to $28 \mathrm{~kJ} \mathrm{~mol}^{-1}$ relative to $2 \mathbf{b}^{+\bullet}$. This analysis indicates that reorientation in the $\boldsymbol{c}$-ion- $\boldsymbol{z}$-radical complexes followed by $c$-ion isomerization is the energetically favorable pathway for fragment formation.

We note that the activation energies for $\mathrm{N}-\mathrm{C}_{\alpha}$ bond dissociations between the Ala-Lys and Lys-Ala residues in TS2 and TS6, respectively, are at the high end of the typical energy range for analogous dissociations in peptide radicals and cation radicals $\left(2-71 \mathrm{~kJ} \mathrm{~mol}^{-1}\right)[66]$. Such relatively high TS energies are presumably due to the conformational changes from the aminoketyl reactants to the pertinent TS rather than to some unusual electronic properties. The reactants $\left(\mathbf{1 d}^{+\cdot}\right.$ and $\left.\mathbf{2 \mathbf { c } ^ { + \bullet }}\right)$ are proper aminoketyl radicals [66], judging by their pyramidized geometry and oddelectron density. The conformational effects are illustrated with the $\mathrm{N}-\mathrm{C}_{\alpha}$ bond cleavage in $\mathbf{1 \mathbf { d } ^ { + \cdot }}$, for which we found three transition states that differed in their conformations with energies ranging from 69 to $91 \mathrm{~kJ} \mathrm{~mol}^{-1}$.

PCET involving the Lys $\varepsilon$-ammonium hydrogen migration to the Lys-Ala amide group in $\mathbf{2 a}^{+\cdot}$ can also be explained using the electronic state energies and orbital analysis (Figure $\mathrm{S} 3$ of the ESM). The SOMO in $\mathbf{2 a}^{+\bullet}$ shows odd-electron delocalization over the DMAP moiety, as confirmed by the calculated spin densities. To reach the TS for PCET (TS5), the electron density must flow into the LysAla amide group. This can be realized by mixing the $\boldsymbol{X}$ and $\boldsymbol{A}$ states in $\mathbf{2 \mathbf { a } ^ { + \bullet }}$ to form the SOMO in TS5 (Figure S3 of the ESM).

\section{Conclusions}

Electron-transfer dissociation of short peptide ions tagged with fixed-charge groups that were previously designed on the basis of electronic structure analysis and attached to the $\mathrm{N}$-terminus showed increased abundance of backbone fragments and decreased side-chain losses when compared to the ETD of the parent, underivatized, peptide ions. The 4dimethylaminopyridinium tag, attached to the peptide by a methylcarboxamide linker (DMAP-ac), appears to be particularly effective at providing informative ETD spectra with a balanced abundance of $\boldsymbol{c}$-type fragment ions carrying the fixed-charge tag. Further exploration of the potential of the DMAP-ac tag for larger peptides is in progress in this laboratory. 


\section{Acknowledgements}

Thanks are due to Dr. Priska von Haller of the University of Washington Proteomics Resource Center for access to the Thermo LTQ XL instrument. Research support from the NSF (grants CHE-0750048 for experiments and CHE0342956 for computations) is gratefully acknowledged. The Department of Chemistry Computer Facility has been jointly supported by the NSF and University of Washington.

\section{References}

1. Syka, J.E.P., Coon, J.J., Schroeder, M.J., Shabanowitz, J., Hunt, D.F.: Peptide andprotein sequence analysis by electron transfer dissociation mass spectrometry. Proc. Natl Acad. Sci. USA. 101, 9528-9533 (2004)

2. Boltalina, O.V., Hvelplund, P., Jørgensen, T.J.D., Larsen, M.C., Larsson, M.O., Sharoitchenko, D.A., Sørensen, M.: Electron capture by fluorinated fullerene anions in collisions with Xe atoms. Phys. Rev. A. 62, 023202 (2000)

3. Fung, Y.M.E., Chan, T.W.D.: Experimental and theoretical investigations of the loss of amino acid side chains in electron capture dissociation of model peptides. J. A. m. Soc. Mass Spectrom. 16, 1523-1535 (2005)

4. Cooper, H.J.: Investigation of the presence of $b$ ions in electron capture dissociation mass spectra. J. Am. Soc. Mass Spectrom. 16, 1932-1940 (2005)

5. Xia, Y., Gunawardena, H.P., Erickson, D.E., McLuckey, S.A.: Effects of cation charge-site identity and position on electrontransfer dissociation of polypeptide cations. J. Am. Chem. Soc. 129, 12232-12243 (2007)

6. Chan, W.Y.K., Chan, T.W.D.: Natural structural motifs that suppress peptide ion fragmentation after electron capture. J. Am. Soc. Mass Spectrom. 21, 1235-1244 (2010)

7. Iavarone, A.T., Paech, K., Williams, E.R.: Effects of charge state and cationizing agent on the electron capture dissociation of a peptide. Anal. Chem. 76, 2231-2238 (2004)

8. Jensen, C.S., Holm, A.I.S., Zettergren, H., Overgaard, J.B., Hvelplund, P., Nielsen, S.B.: On the charge partitioning between $\mathrm{c}$ and $\mathrm{z}$ fragments formed after electron-capture induced dissociation of charge-tagged Lys-Lys and Ala-Lys dipeptide dications. J. Am. Soc. Mass Spectrom. 20, 1881-1889 (2009)

9. Tsybin, Y.O., Haselmann, K.F., Emmett, M.R., Hendrickson, C.L., Marshall, A.G.: Charge location directs electron capture dissociation of peptide dications. J. Am. Soc. Mass Spectrom. 17, 1704-1711 (2006)

10. Breuker, K., Oh, H.B., Horn, D.M., Cerda, B.A., McLafferty, F.W.: Detailed unfolding and folding of gaseous ubiquitin ions characterized by electron capture dissociation. J. Am. Chem. Soc. 124, 6407-6420 (2002)

11. Mihalca, R., Kleinnijenhuis, A.J., McDonnell, L.A., Heck, A.J.R., Heeren, R.M.A.: Electron capture dissociation at low temperatures reveals selective dissociations. J. Am. Soc. Mass Spectrom. 15, 1869 1873 (2004)

12. Adams, C.M., Kjeldsen, F., Zubarev, R.A., Budnik, B.A., Haselmann, K.F.: Electron capture dissociation distinguishes a single D-amino acid in a protein and probes the tertiary structure. J. Am. Soc. Mass Spectrom. 15, 1087-1097 (2004)

13. Adams, C.M., Kjeldsen, F., Patriksson, A., van der Spoel, D., Graslund, A., Papadopoulos, E., Zubarev, R.A.: Probing solution- and gas-phase structures of Trp-cage cations by chiral substitution and spectroscopic techniques. Int. J. Mass Spectrom. 253, 263-273 (2006)

14. Robinson, E.W., Leib, R.D., Williams, E.R.: The role of conformation on electron capture dissociation of ubiquitin. J. Am. Soc. Mass Spectrom. 17, 1469-1479 (2006)

15. Tureček, F., Chen, X., Hao, C.: Where does the electron go? Electron distribution and reactivity of peptide cation-radicals formed by electron transfer in the gas phase. J. Am. Chem. Soc. 130, 8818-8833 (2008)

16. Panja, S., Nielsen, S.B., Hvelplund, P., Tureček, F.: Inverse hydrogen atom migration in arginine-containing peptide ions upon electron transfer. J. Am. Soc. Mass Spectrom. 19, 1726-1742 (2008)

17. Brancia, F.L., Oliver, S.G., Gaskell, S.J.: Improved matrix-assisted laser desorption/ionization mass spectrometric analysis of tryptic hydro- lysates of proteins following guanidination of lysine-containing peptides. Rapid Commun. Mass Spectrom. 14, 2070-2073 (2000)

18. Peters, E.C., Horn, D.M., Tully, D.C., Brock, A.: A novel multifunctional labeling reagent for enhanced protein characterization with mass spectrometry. Rapid Commun. Mass Spectrom. 15, 2387-2392 (2001)

19. Beardsley, R.L., Reilly, J.P.: Optimization of guanidination procedures for MALDI mass mapping. Anal. Chem. 74, 1884-1890 (2002)

20. Ji, C., Guo, N., Li, L.: Differential dimethyl labeling of N-termini of peptides after guanidination for proteome analysis. J. Proteome Res.4, 2099-2108 (2005)

21. Warwood, S., Mohammed, S., Cristea, I.M., Evans, C., Whetton, A.D., Gaskell, S.J.: Guanidination chemistry for qualitative and quantitative proteomics. Rapid Commun. Mass Spectrom. 20, 3245-3256 (2006)

22. Conrotto, P., Hellman, U.: Lys Tag: an easy and robust chemical modification for improved de novo sequencing with a matrix-assisted laser desorption/ionization tandem time-of-flight mass spectrometer. Rapid Commun. Mass Spectrom. 22, 1823-1833 (2008)

23. Hennrich, M.L., Boersema, P.J., van den Toorn, H., Mischerikow, N., Heck, A.J.R., Mohammed, S.: Effect of chemical modifications on peptide fragmentation behavior upon electron transfer induced dissociation. Anal. Chem. 81, 7814-7822 (2009)

24. Roth, K.D.W., Huang, Z.-H., Sadagopan, N., Watson, J.T.: Charge derivatization of peptides for analysis by mass spectrometry. Mass Spectrom. Rev. 17, 255-274 (1999)

25. Vath, J.E., Biemann, K.: Microderivatization of peptides by placing a fixed positivecharge at the N-terminus to modify high energy collision fragmentation. Int. J. Mass Spectrom. Ion Process. 100, 287-299 (1990)

26. Jones, J.W., Sasaki, T., Goodlett, D.R., Tureček, F.: Electron capture in spin-trap capped peptides. An experimental example of ergodic dissociation in peptide cation-radicals. J. Am. Soc. Mass Spectrom. 18, 432-444 (2007)

27. Shen, T.L., Allison, J.: Interpretation of matrix-assisted laser desorption/ ionization postsource decay spectra of charge-derivatized peptides: some examples of tris[ $(2,4,6$ - trimethoxyphenyl)phosphonium]-tagged proteolytic digestion products of phosphoenol-pyruvate carboxykinase. J. Am. Soc. Mass Spectrom. 11, 145-152 (2000)

28. Chamot-Rooke, J., van der Rest, G., Dalleu, A., Bay, S., Lemoine, J.: The combination of electron capture dissociation and fixed charge derivatization increases sequence coverage for O-glycosylated and O-phosphorylated peptides. J. Am. Soc. Mass Spectrom. 18, 1405 (2007)

29. Chamot-Rooke, J., Malosse, C., Frison, G., Tureček, F.: Electron capture in charge-tagged peptides. Evidence for the role of excited electronic states. J. Am. Soc. Mass Spectrom. 18, 2146 (2007)

30. Ren, D., Julka, S., Inerowicz, H.D., Regnier, F.E.: Enrichment of cysteine-containing peptides from tryptic digests using a quaternary amine tag. Anal. Chem. 76, 4522-4530 (2004)

31. Chung, T.W., Tureček, F.: Selecting fixed-charge groups for electronbased peptide dissociations. A computational study of pyridinium tags. Int. J. Mass Spectrom. 276, 127-135 (2008)

32. Chung, T.W., Tureček, F.: Electron transfer to charge-tagged peptide ions. A computational analysis of electronic states. Eur. J. Mass Spectrom. 14, 367-378 (2008)

33. Chen, X., Tureček, F.: The arginine anomaly: arginine radicals are poor hydrogen atom donors in electron transfer induced dissociations. J. Am. Chem. Soc. 128, 12520-12530 (2006)

34. Syrstad, E.A., Tureček, F.: Toward a general mechanism of electroncapture dissociation. J. Am. Soc. Mass Spectrom. 16, 208-224 (2005)

35. Sobczyk, M., Anusiewicz, I., Berdys-Kochanska, J., Sawicka, A., Skurski, P., Simons, J.: Coulomb-assisted dissociative electron attachment: application to a model peptide. J. Phys. Chem. A. 109, 250-258 (2005)

36. Phillips, J.C., Braun, R., Wang, W., Gumbart, J., Tajkhorshid, E., Villa, E., Chipot, C., Skeel, R.D., Kale, L., Schulten, K.: Scalable molecular dynamics with NAMD. J. Comp. Chem. 26, 1781-1802 (2005)

37. Frisch, M.J., Trucks, G.W., Schlegel, H.B., Scuseria, G.E., Robb, M.A., Cheeseman, J.R., Scalmani, G., Barone, V., Mennucci, B., Petersson, G. A., Nakatsuji, H., Caricato, M., Li, X., Hratchian, H.P., Izmaylov, A.F., Bloino, J., Zheng, G., Sonnenberg, J.L., Hada, M., Ehara, M., Toyota, K., Fukuda, R., Hasegawa, J., Ishida, M., Nakajima, T., Honda, Y., Kitao, O., Nakai, H., Vreven, T., Montgomery Jr., J.A., Peralta, J.E., Ogliaro, F., Bearpark, M., Heyd, J.J., Brothers, E., Kudin, K.N., Staroverov, V.N., Kobayashi, R., Normand, J., Raghavachari, K., Rendell, A., Burant, J.C., Iyengar, S.S., Tomasi, J., Cossi, M., Rega, N., Millam, J.M., Klene, M., Knox, J.E., Cross, J.B., Bakken, V., 
Adamo, C., Jaramillo, J., Gomperts, R., Stratmann, R.E., Yazyev, O., Austin, A.J., Cammi, R., Pomelli, C., Ochterski, J.W., Martin, R.L., Morokuma, K., Zakrzewski, V.G., Voth, G.A., Salvador, P., Dannenberg, J.J., Dapprich, S., Daniels, A.D., Farkas, O., Foresman, J.B., Ortiz, J.V., Cioslowski, J., Fox, D.J.: Gaussian 09, revision A.02. Gaussian, Inc., Wallingford, CT (2009)

38. MacKerell Jr., A.D., Bashford, D., Bellott, M., Dunbrack Jr., R.L., Evanseck, J.D., Field, M.J., Fischer, S., Gao, J., Guo, H., Ha, S., Joseph-McCarthy, D., Kuchnir, L., Kuczera, K., Lau, F.T.K., Mattos, C., Michnick, S., Ngo, T., Nguyen, D.T., Prodhom, B., Reiher III, W. E., Roux, B., Schlenkrich, M., Smith, J.C., Stote, R., Straub, J., Watanabe, M., Wiorkiewicz-Kuczera, J., Yin, D., Karplus, M.: All-atom empirical potential for molecular modeling and dynamics studies of proteins. J. Phys. Chem. B. 102, 3586-3616 (1998)

39. Sugita, Y., Okamoto, Y.: Replica-exchange molecular dynamics method for protein folding. Chem. Phys. Lett. 314, 141-151 (1999)

40. Stewart, J.J.P.: Optimization of parameters for semiempirical methods. V. Modification of NDDO approximations and application to 70 elements. J. Mol. Model. 13, 1173-1213 (2007)

41. Becke, A.D.: Mixing of Hartree-Fock and local density-functional theories. J. Chem. Phys. 98, 1372-1377 (1993)

42. Becke, A.D.: Density functional thermochemistry. III. The role of exact exchange. J. Chem. Phys. 98, 5648-5652 (1993)

43. Stephens, P.J., Devlin, F.J., Chabalowski, C.F., Frisch, M.J.: Ab initio calculation of vibrational absorption and circular dichroism spectra using density functional force fields. J. Phys. Chem. 98, 11623-11627 (1994)

44. Møller, C., Plesset, M.S.: A note on an approximation treatment for many-electron systems. Phys. Rev. 46, 618-622 (1934)

45. Tureček, F.: Proton affinity of dimethyl sulfoxide and relative stabilities of $\mathrm{C}_{2} \mathrm{H}_{6} \mathrm{OS}$ molecules and $\mathrm{C}_{2} \mathrm{H}_{7} \mathrm{OS}^{+}$ions. A comparative G2(MP2) ab initio and density functional theory study. J. Phys. Chem. A. 102, 47034713 (1998)

46. Furche, F., Ahlrichs, R.: Adiabatic time-dependent density functional methods for excited state properties. J. Chem. Phys. 117, 7433-7447 (2002)

47. Roepstorff, P., Fohlman, J.: Proposal for a common nomenclature for sequence ions in mass spectra of peptides. Biomed. Mass Spectrom. 1, 601 (1984)

48. Biemann, K.: Contributions of mass spectrometry to peptide and protein structure. Biomed. Environ. Mass Spectrom. 16, 99-111 (1988)

49. Zubarev, R.A., Horn, D.M., Fridriksson, E.K., Kelleher, N.L., Kruger, N.A., Lewis, M.A., Carpenter, B.K., McLafferty, F.W.: Electron capture dissociation for structural characterization of multiply charged protein cations. Anal. Chem. 72, 563-573 (2000)

50. Tureček, F., Chung, T.W., Moss, C.L., Wyer, J.A., Ehlerding, A., Zettergren, H., Nielsen, S.B., Hvelplund, P., Chamot-Rooke, J., Bythell, B., Paizs, B.: The histidine effect. Electron transfer and capture cause different dissociations and rearrangements of histidine peptide cationradicals. J. Am. Chem. Soc. 132, 10728-10740 (2010)
51. Chaudhuri, J., Jagur-Grodzinski, J., Szwarc, M.: Electron affinities of aromatic hydrocarbons in the gas phase and in solution. J. Phys. Chem. 71, 3063-3065 (1967)

52. Maddams, W.F., Schnurmann, R.: Ultraviolet absorption spectrum of fluoranthene. J. Chem. Phys. 19, 973-974 (1951)

53. Michl, J.: Electronic spectrum of fluoranthene. J. Mol. Spectrosc. 30, 66-76 (1969)

54. Ruth, A.A., Wick, M.T.: The S-0->S-4 transition of jet-cooled fluoranthene: vibronic coupling of S-4 with S-3. Chem. Phys. Lett. 266, 206-216 (1997)

55. Tureček, F., Syrstad, E.A.: Mechanism and energetics of intramolecular hydrogen transfer atom transfer in amide and peptide radicals and cation-radicals. J. Am. Chem. Soc. 125, 3353-3369 (2003)

56. Tureček, $\mathrm{F} .: \mathrm{N}-\mathrm{C}_{\alpha}$ bond dissociation energies and kinetics in amide and peptide radicals. Is the dissociation a non-ergodic process? $\mathrm{J} . \mathrm{Am}$. Chem. Soc. 125, 5954-5963 (2003)

57. Siegbahn, P.E.M., Blomberg, M.R.A., Crabtree, R.H.: Hydrogen transfer in the presence of amino acid radicals. Theor. Chim. Acc. 97, 289300 (1997)

58. Siegbahn, P.E.M., Ericsson, L., Himo, F., Pavlov, M.: Hydrogen atom transfer in ribonucleotide reductase (RNR). J. Phys. Chem. B. 102, 10622-10629 (1998)

59. Cukier, R.I., Nocera, D.G.: Proton-coupled electron transfer. Annu. Rev. Phys. Chem. 49, 337-369 (1998)

60. Gellene, G.I., Porter, R.F.: Neutralized ion-beam spectroscopy. Acc. Chem. Res. 16, 200-207 (1983)

61. Shaffer, S.A., Turecek, F.: Hydrogentrimethylammonium: a marginally stable hypervalent radical. J. Am. Chem. Soc. 116, 8647-8653 (1994)

62. Yao, C., Tureček, F.: Hypervalent ammonium radicals. Competitive N$\mathrm{C}$ and $\mathrm{N}-\mathrm{H}$ bond dissociations in methylammonium and ethylammonium. Phys. Chem. Chem. Phys. 7, 912-920 (2005)

63. Hayakawa, S., Hashimoto, M., Matsubara, H., Tureček, F.: Dissecting the proline effect: dissociations of proline radicals formed by electron transfer to protonated Pro-Gly and Gly-Pro dipeptides in the gas phase. J. Am. Chem. Soc. 129, 7936-7949 (2007)

64. Tureček, F., Syrstad, E.A., Seymour, J.L., Chen, X., Yao, C.: Peptide cation-radicals. A computational study of the competition between peptide $\mathrm{N}-\mathrm{C}_{\alpha}$ bond cleavage and loss of the side chain in the $\left[\text { GlyPhe- } \mathrm{NH}_{2}+2 \mathrm{H}\right]^{+\bullet}$ cation radical. J. Mass Spectrom. 38, 10931104 (2003)

65. Frison, G., Bull, A., van der Rest, G., Tureček, F., Besson, T., Lemaire, J., Maître, P., Chamot-Rooke, J.: Structure of ECD fragments from charge-tagged peptides probed by tunable IRMPD. J. Am. Chem. Soc. 130, 14916-14917 (2008)

66. Chung, T.W., Tureček, F.: Proper and improper aminoketyl radicals in electron-based peptide dissociations. Int. J. Mass Spectrom. (2011). doi:10.1016/j.ijms.2010.06.025 